\title{
The genus Nitzschia on the South Shetland Islands and James Ross Island
}

\author{
Sarah Hamsher ${ }^{1}$, Kateřina Kopaloví ${ }^{2,3}$, J. Patrick Kociolek ${ }^{1}$, Ralitsa Zidarova ${ }^{4}$ \& \\ Bart VAN DE VIJVER ${ }^{5,6^{*}}$
}

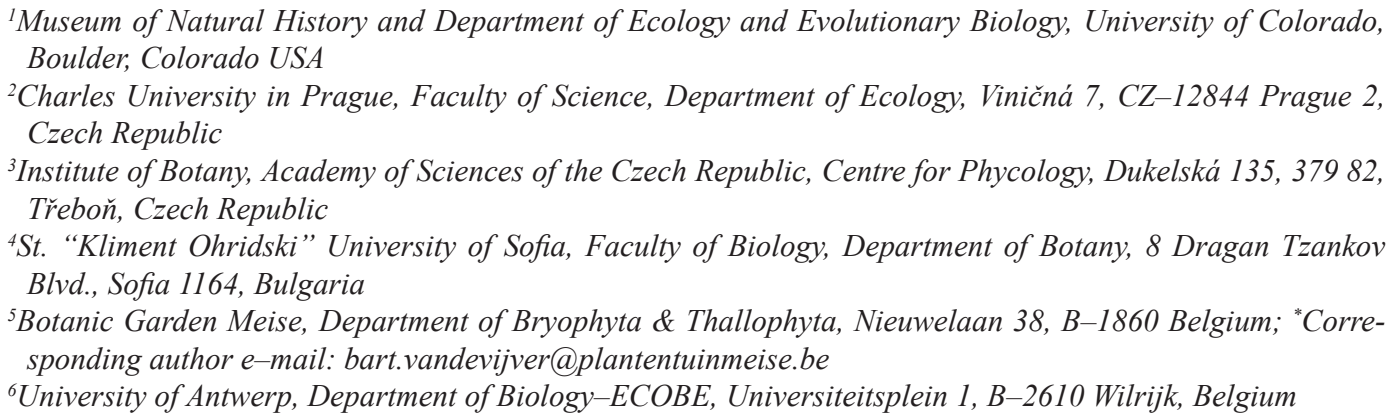

\begin{abstract}
The purpose of this study was to present LM and SEM observations of Nitzschia taxa encountered on the South Shetland Islands and James Ross Island. During the ongoing taxonomical revision of the freshwater and limno-terrestrial diatom flora on the South Shetland Islands and James Ross Island (Maritime Antarctic Region) eight unknown taxa belonging to the genus Nitzschia were found. These taxa were previously forcefitted into European names such as $N$. commutata or $N$. perminuta, but detailed light and scanning electron microscopical observations allowed their separation from the already known taxa and resulted in the description of eight new species. The paper discusses all twelve Nitzschia taxa found in the Maritime Antarctic Region. New taxa are compared to the morphologically most similar taxa and their ecology and biogeography are discussed. Although the genus Nitzschia is present worldwide, a large number of Nitzschia taxa have a restricted distribution within the Antarctic Region, showing a clear bioregionalism.
\end{abstract}

Key words: Nitzschia, Bacillariophyta, Maritime Antarctic Region, new species, taxonomy

\section{INTRODUCTION}

The Maritime Antarctic Region is defined as the region north of the so-called Gressit-line, between $70^{\circ} \mathrm{S}$ and $55^{\circ} \mathrm{S}$ and includes a series of islands and archipelagos as well as the west coast of the Antarctic Peninsula south to Marguerite Bay (CHOwn \& Convey 2007; Kopaloví et al. 2014). The region is characterized by a sparse and species-low tundra with lichens and mosses dominating the landscape (Kopaloví et al. 2013, 2014).

Prior to 2008, the diatom flora of Maritime Antarctic Region was only poorly studied, resulting in older floras mainly composed of cosmopolitan taxa (Kopaloví et al. 2014). As a consequence, these older floras underestimated the diatom species richness in the region by lumping many discrete morphologies into a single species or force-fitting presumably new species into European and North American relatives (KopA-
Lová et al. 2009; Kopalová \& Van de ViJver 2013). Recently however, in the framework of a detailed survey of the Maritime Antarctic diatom flora applying a more fine-grained taxonomy, a large number of new species, in for instance the genera Hantzschia GRUNOw, Luticola D.G.Mann in Round, R.M.Crawford, \& D.G. Mann, Muelleria (Freng.) Freng., Pinnularia Ehrenb. and Stauroneis EhrenB. were observed and described (e.g., VAn de Vijver \& Mataloni 2008; Kopalová et al. 2011; VAN DE VIJVER et al. 2010, 2011, 2014; ZidAROVA et al. 2010, 2012, 2014). These studies led to the overall conclusion that not all Maritime Antarctic islands share a similar flora and while the diversity of this flora is limited compared to more temperate or tropical localities, many of the newly discovered taxa are endemic to the region and not cosmopolitan as was previously reported (VAN DE ViJVER et al. 2005; KopalovÁ et al. 2014).

The present study focuses on the genus Nitz- 
schia HASSALL observed in two localities within the Maritime Antarctic Region: the South Shetland Islands and James Ross Island. Only a few freshwater Nitzschia species have been described from the Antarctic Region. Two species were described from continental Antarctica: N. frauenfeldii var. antarctica Perag. (Peragallo 1921) and N. westiorum T.E.Kellogg et D.B.Kellogg (Kellogg et al. 1980; Van de Vijver et al. 2012). Manguin (in Bourrelly \& Manguin 1954) described one new variety ( $N$. frustulum var. kerguelenensis MANGUIN) and one new forma (Nitzschia ignorata f. longissima MANGUIN) from the sub-Antarctic Kerguelen Islands. On the nearby Crozet archipelago, VAN DE VIJVER et al. (2002) described $N$. chardezii VAN DE ViJver \& Beyens. Apart from these four taxa, previous literature reports on the Nitzschia flora from the Antarctic Region suggest that only cosmopolitan taxa such as $N$. commutata GRUNOw and $N$. perminuta (GRUnow) Perag. (Kellogg \& Kellogg 2002 and references therein) are present.

The purpose of this study is to illustrate twelve Nitzschia taxa observed on the South Shetland Islands (Livingston Island, Deception Island, King George Island, Nelson Island and Dart Island) and James Ross Island (Clearwater Mesa and Ulu Peninsula), including the description of 8 new species using LM and SEM observations. The species are compared with similar taxa worldwide. Notes on their ecology and distribution in the Maritime Antarctic Region are included.

\section{Materials And Methods}

Samples were collected from various aquatic and terrestrial habitats on the South Shetland Islands and several lakes on
Clearwater Mesa and Ulu Peninsula (James Ross Island) (Fig. 1). The South Shetland Islands (SSI), situated just north of the Antarctic Peninsula $\left(63^{\circ} 00^{\prime} \mathrm{S}, 60^{\circ} 00^{\prime} \mathrm{W}\right)$, consist of several larger and many smaller islands and islets, with King George Island $\left(1150 \mathrm{~km}^{2}\right)$ and Livingston Island $(972$ $\mathrm{km}^{2}$ ) being the largest. Other important islands include Deception Island, Nelson Island and Snow Island. Most of the landmasses are covered by permanent ice and snow, leaving only small parts ice-free. The terrestrial vegetation is limited to lichens and mosses with only two flowering plants (Colobanthus quitensis [KunTH] BARTLING and Deschampsia antarctica DESVAUX). The climate is typically maritime with mean annual temperatures around $-5^{\circ} \mathrm{C}$, high precipitation rates and strong westerly winds (ChIPEV \& Veltchev 1996). The largest ice-free area on Livingston Island, Byers Peninsula $\left(60.6 \mathrm{~km}^{2}\right)$, situated in the western part of island, is dominated by a central plateau with a gently undulating relief culminating at a maximum elevation of $265 \mathrm{~m}$ (Cerro Start). More than 100 lakes and ponds of variable size are scattered over the entire peninsula, covering about $1.5 \%$ of its area (LÓPEZ-MARTínez et al. 1996a, b). More information about the geology and hydrography of Byers Peninsula can be found in Toro et al. (2007).

James Ross Island (JRI) $\left(64^{\circ} 10^{\prime} \mathrm{S}, 57^{\circ} 45^{\prime} \mathrm{W}\right)$ is a large island $\left(2450 \mathrm{~km}^{2}\right)$ located further south than the SSI in the Maritime Antarctic Region, in the northwestern part of the Weddell Sea, close to the northern tip of the Antarctic Peninsula. The island is situated in the transition zone between the Maritime Antarctic Region and the Antarctic Continent (Øvstedal \& Lewis-Smith 2001). Only its northern part, the Ulu Peninsula, is ice-free. Another area on JRI, Clearwater Mesa, is a volcanic tableland composed of single hyaloclastite breccia unit capped with subaerial basalt of the JRI Volcanic Group (Nelson 1975; KoŠLER et al. 2009). On the flat mesa surface (mostly 250-300 m a.s.1.) tens of lakes evolved after the glacier retreat during the early Holocene (NedBaloví et al. 2013). These lakes with a littoral zone covered by microbial mats are generally shallow and usually old with a persistence of thousands of years (Nedbaloví et al. 2013). The terrestrial vegetation is limited to non-vascular
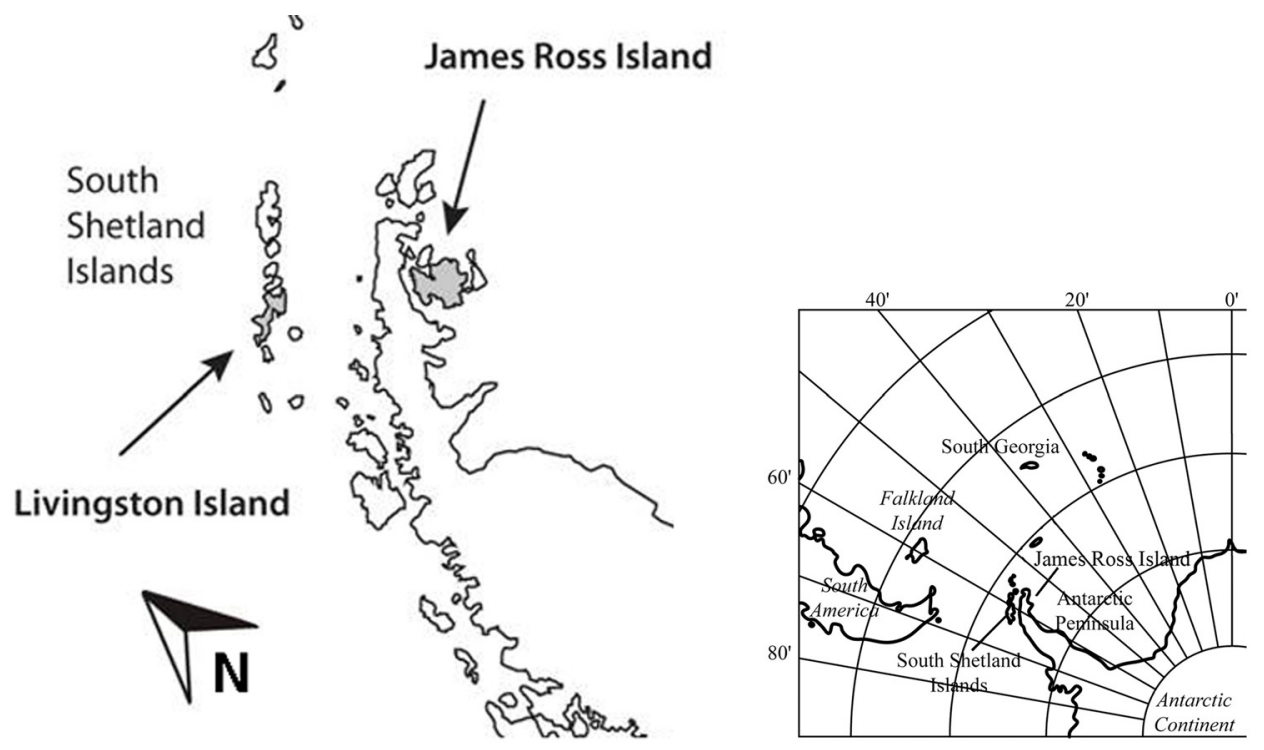

Fig. 1. Location of the South Shetland Islands and James Ross Island in the southern hemisphere near the Antarctic Peninsula. The inset map shows the western half of the entire southern hemisphere locating the position of the Peninsular region. 
plants, forming a bryophyte-lichen tundra. The temperature is comparable to the SSI but precipitation is limited to only $150 \mathrm{~mm} / \mathrm{y}$ in the northern part (ARISTARAIN et al. 1987), with high evaporation rates reducing the formation of large open water bodies.

Sampling methods follow those described in KoPALOVÁ et al. $(2012,2013,2014)$ and Kopalová \& VAN DE VIJVER (2013). Details on the physico-chemical analyses, recorded from Livingston Island and James Ross Island ( $\mathrm{pH}$, conductivity, nutrients) can be found likewise in these references. On King George Island, Nelson Island and Dart Island (SSI) only water temperature, specific conductance value and $\mathrm{pH}$ were measured in situ using Hanna ${ }^{\circledR}$ testers

Diatom samples were prepared following the method described in VAN DER WERFF (1955). Small parts of the samples were cleaned by adding $37 \% \mathrm{H}_{2} \mathrm{O}_{2}$ and heating to $80{ }^{\circ} \mathrm{C}$ for about one hour, followed by addition of $\mathrm{KMnO}_{4}$. After digestion and centrifugation $(3 \times 10$ minutes at $3700 \mathrm{~g})$, the material was diluted with distilled water to avoid excessive concentrations of diatom valves. Cleaned diatom valves were mounted in Naphrax ${ }^{\circledR}$. Samples and slides are stored at the BR-collection, property of the Belgian Federal Government and given on permanent loan to the Botanic Garden Meise (Belgium). The slides were analyzed using an Olympus BX53 microscope, equipped with Differential Interference Contrast and the Colorview I Soft Imaging System. For scanning electron microscopy (SEM), part of the suspension was filtered through polycarbonate membrane filters with a pore diameter of $1 \mu \mathrm{m}$, pieces of which were fixed on aluminum stubs after air-drying. The stubs were sputter-coated with 20 $\mathrm{nm}$ of $\mathrm{Au}-\mathrm{Pd}$ and studied in a Zeiss Ultra microscope at $3 \mathrm{kV}$. Terminology is based on Hendey (1964), Ross et al. (1979) and Round et al. (1990). Stria and fibulae density were determined in counting striae and fibulae in $10 \mu \mathrm{m}$, starting near the valve center to one of the apices. For each new taxon, the number of specimens measured at random on the type slide is indicated $(n=X)$.

\section{Results}

A total of twelve Nitzschia taxa were observed in the investigated material. After a thorough morphological analysis based on light and scanning electron microscopy observations, only four were already known taxa: Nitzschia gracilis Hantzsch, N. homburgiensis Lange-Bertalot, $N$. paleacea Grunow and $N$. soratensis E.A.Morales et M.L.VIS. Eight species could not be identified and are described as new: Nitzschia annewillemsiana sp. nov., $N$. australocommutata sp. nov., N. kleinteichiana sp. nov., N. stelmachpessiana sp. nov., $N$. vancauwenberghiana sp. nov., $N$. vandeputteana sp. nov., $N$. velazqueziana sp. nov. and $N$. wilmottiana sp. nov.

\section{Nitzschia annewillemsiana sp. nov. (Figs 2-22)}

\section{Description}

Light microscopy (Figs 2-18): Frustules with nitzschioid symmetry. Valves lanceolate in valve view, with convex margins, tapering gradually to acutely rounded, never protracted apices. Valve dimensions $(\mathrm{n}=50)$ : length $10-20 \mu \mathrm{m}$, width 3-4 $\mu \mathrm{m}$. Striae clearly punctate, parallel at the center of the valve, becoming weakly curved and convergent towards the apices, 24-26 in $10 \mu \mathrm{m}$. Robust marginal fibulae evenly spaced but of varying widths with a distinct central nodule present on some specimens, $11-12$ in $10 \mu \mathrm{m}$. Canal raphe eccentric, raised on a keel above the surface of the valve. Raphe slit not continuous.

Scanning electron microscopy (Figs 19-22): Raphe situated on the border between the valve face and the mantle, on a slight keel above the surface of the valve. Hyaline area present opposite the raphe. Raphe not continuous. External proximal raphe endings slightly deflected, almost not enlarged. Distal raphe fissures strongly hooked. Striae uniseriate, evenly spaced throughout the valve, mostly composed of large, elliptical areolae. Striae from the valve face and the mantle ending in one, occasionally two rows of two smaller, round areolae, on both sides of the raphe. Virgae are slightly thicker than vimines, especially closest to the raphe. Elliptical areolae are occluded by hymenes. Internal proximal raphe endings terminating in simple pores on a thickened central nodule. Internal distal raphe endings terminating in helictoglossae prior to the hook of the external terminal fissure. Internally, canal raphe subtended by fibulae widening to the valve face to form round portulae. Fibulae evenly spaced throughout the valve, every 1-2 striae.

Holotype: BR-4409 (Botanic Garden Meise, Belgium), Fig. 4 represents the holotype specimen.

Isotypes: PLP-280 (University of Antwerp, Belgium), BRM-ZU10/20 (HustedT Collection, Bremerhaven, Germany).

Type locality: Red Lake, Ulu Peninsula, James Ross Island, sample JRI-D28 (635' $33.3^{\prime \prime S}, 57^{\circ} 47^{\prime} 46.3^{\prime \prime}$ W) (Leg. L. NedBAlovÁ); coll. date 22/02/2008).

Etymology: The species is named after Prof. Dr. ANNE WiLlems (Ghent University, Belgium), principal investigator of the CCAMBIO project.

Ecology and Distribution: Nitzschia annewillemsia$n a$ has so far been observed with certainty on James Ross Island as well as on Livingston Island and King George Island (South Shetland Islands). It is likely it is much more widespread in Antarctica, but has most likely been recorded as Nitzschia frustulum (KüTZ.) GRUNOw or N. perminuta, making its actual distribution unknown. On King George Island small populations were found on the bottom of small brooks and ponds/ lakes having an alkaline $\mathrm{pH}(7.8-8.5)$ and low specific conductance values $\left(85-202 \mu \mathrm{S} . \mathrm{cm}^{-1}\right)$. Another relatively large population was found occurring in wet mosses surrounding a small shallow brook. On Livingston Island, $N$. annewillemsiana was often recorded in small brooks and on very wet soil around water bodies. 
Taxonomic Remarks: Nitzschia annewillemsiana was previously identified as part of the Nitzschia perminuta-complex as ' $N$. perminuta-non-capitate form' (KoPAlOVÁ \& VAN de ViJver 2013; Kopalová et al. 2013). It can be separated from the other two taxa that were split off ( $N$. kleinteichiana sp. nov. and $N$. velazqueziana sp. nov., see below) by the lack of protracted valve apices, the less linear but clearly lanceolate valve outline (with typically convex valve margins) and the typical punctate striae, clearly visible in LM. In both other taxa, areolae are less discernible in LM. The most similar species (in LM), based on valve outline, appears to be $N$. frustulum (KüTZ.) GRUNOw but the latter can be separated by the structure of the striae. In $N$. frustulum, the striae terminate at the raphe in one single areola, not differentiated from the other areolae (TROBAJO et al. 2013) whereas in N. annewillemsiana, striae terminate in one or two rows of 2 small areolae. This also applies for other Nitzschia species belonging to the same complex such as $N$. inconspicua GrUNOw and $N$. acidoclinata LANGE-BERT. A similar structure can be however found in $N$. soratensis (see for instance our figs $135 \& 137$ ) but the latter has a different valve outline with broadly, obtusely rounded valve apices and parallel, straight margins contrary to the lanceolate, convex valve outline of $N$. annewillemsiana. Nitzschia bulnheimiana (RABENH.) GRUNOw has larger valve dimensions (width 4-4.7 $\mu \mathrm{m}$ ) with a lower stria density (max. 22 in $10 \mu \mathrm{m})$ and a different stria and areola structure (DenYs \& LANGE-BERTALOT 1998). According to Denys \& Lange-Bertalot (1998, Figs 28, 29), areolae in $N$. bulnheimiana only rarely are doubled near the raphe, contrary to $N$. annewillemsiana. Finally, $N$. invisitata HuST. has a somewhat similar valve outline with non-protracted, acutely rounded apices but shows clear differences in the areola structure bordering the raphe as can be seen in TroBajo et al. (2013, Figs 106111).
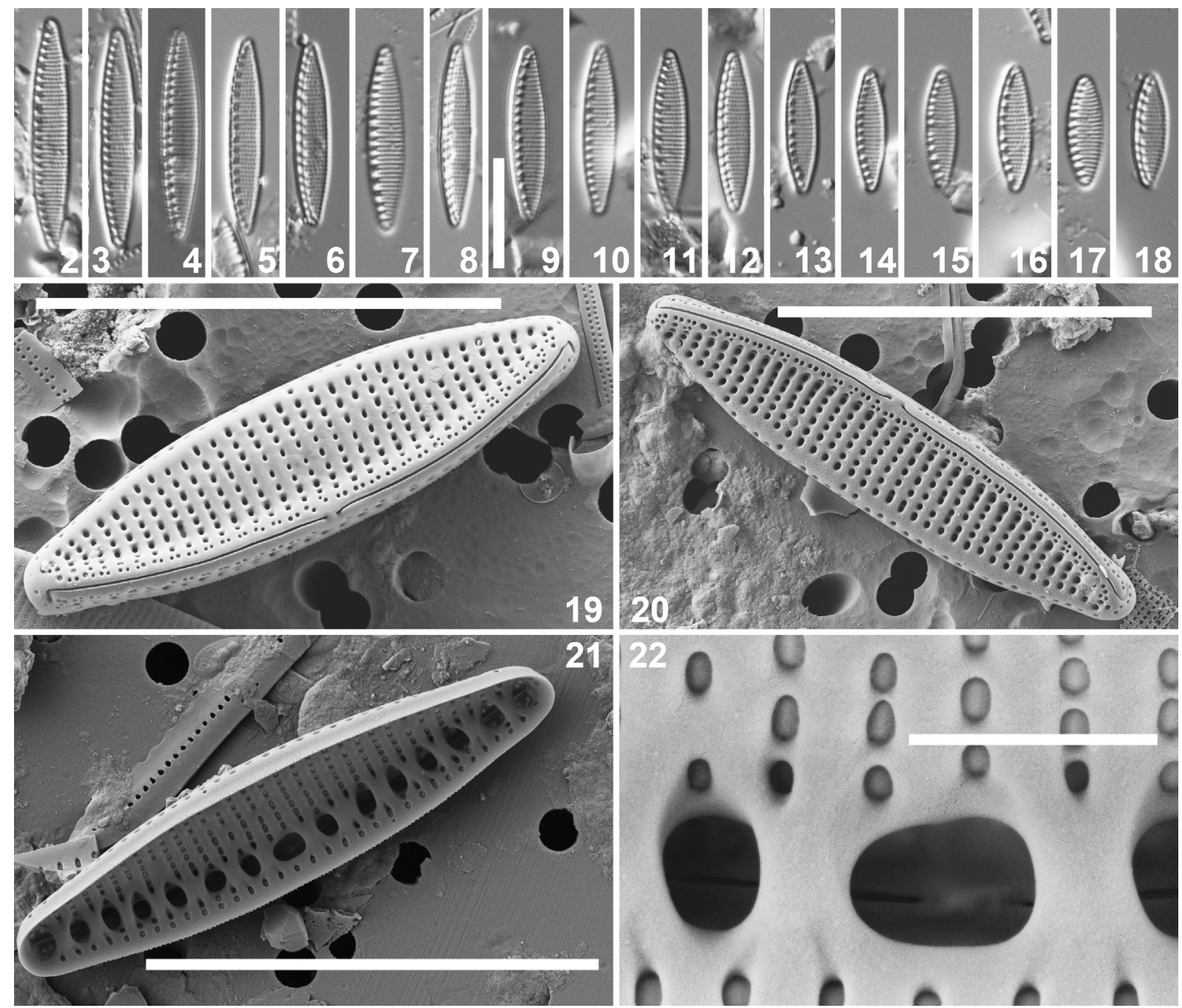

Figs 2-22. Nitzschia annewillemsiana sp. nov.: (2-18) LM. Pictures taken from the type population (Red Lake, Ulu Peninsula, James Ross Island, sample JRI-D28, fig. 4 represents the holotype). Single valves showing observed size range; (19-20) SEM. External whole valve view; (21) SEM. Interior whole valve view; (22) SEM. Detail of internal valve showing proximal raphe ends and occluded striae. Scale bars $10 \mu \mathrm{m}$ $(2-21) ; 1 \mu \mathrm{m}(22)$. 
Nitzschia australocommutata sp. nov. (Figs 23-30, 33-36)

\section{Description}

Light microscopy (Figs 23-30): Frustules with nitzschioid symmetry. In valve view, valves asymmetrical to the apical axis, linear to slightly reniform, asymmetrically constricted in the valve middle, with beak-shaped to rostrate produced apices. Valve dimensions $(n=20)$ : length 55-70 $\mu \mathrm{m}$, width 5-6 $\mu \mathrm{m}$. Striae punctate, mostly parallel with slight convergence towards the central nodule and the apices, $20-21$ in 10 $\mu \mathrm{m}$. Marginal fibulae transapically elongated irregularly spaced, 8-10 in $10 \mu \mathrm{m}$. Distinct central nodule present. Canal raphe eccentric, raised on a keel above the surface of the valve. Raphe slit not continuous.

Scanning electron microscopy (Figs 33-36): Raphe situated on a hyaline area on a keel, positioned on the border between the valve face and the mantle. Raphe not continuous. External proximal raphe endings terminating in a simple pore (Fig. 33), adjacent to a larger fan-shaped hyaline central area (Figs 35, 36) on the valve face. External distal raphe endings strongly hooked. Striae mostly composed of round areolae evenly spaced throughout the valve, with the exception of the hyaline area adjacent to the proximal raphe endings. Virgae wider than vimines. Striae continuing from valve face onto the keel. Areolae externally occluded by perforated hymenes (Fig. 36), 32-35 in $10 \mu \mathrm{m}$. From the interior, canal raphe subtended by fibulae connecting to the valve, continuous with virgae. Portulae absent. Fibulae irregularly spaced, every 1-4 striae.

Holotype: BR-4410 (Botanic Garden Meise, Belgium), fig. 25 represents the holotype.

Isotypes: PLP-281 (University of Antwerp, Belgium), BRM-ZU10/21 (HustedT Collection, Bremerhaven, Germany).

Type locality: Clearwater Lake 3, Clearwater Mesa, James Ross Island, sample CLW-D60 (6401'48.1" S, 5742'49.5"W) (Leg. L. NedBaloví); coll. date 09/02/2009).

Etymology: The specific name refers to the biogeographic distribution of the species in the southern hemisphere and the similarity with $N$. commutata GrUNOW in Cleve \& GRuNOW.

Ecology and distribution: Nitzschia australocommutata has been reported under different names in the earlier Antarctic reports. It was observed in several localities in the Maritime Antarctic Region and the Antarctic Continent and recorded as $N$. commutata, $N$. dubia W.Smith or $N$. dubia var. australis Perag. (KelloGG \& Kellogg 2002). The species was with certainty (illustrated and) reported from the Antarctic Continent by SABBe et al. (2003) and OHtsukA et al. (2006) as $N$. commutata. The type population of $N$. australocommu- tata was observed in a lake on the Clearwater Mesa tableland. The lake was characterized by an alkaline $\mathrm{pH}$ (8.3) and a moderate conductivity $\left(<500 \mu \mathrm{S} . \mathrm{cm}^{-1}\right)$. The new taxon was also found in other lakes of the same area in similar ecological conditions but populations were always very small.

Taxonomic remarks: Nitzschia australocommutata has been frequently confused in past Antarctic reports with $N$. commutata. Analysis of the type material (slide $\mathrm{n}^{\circ} \mathrm{VI}-48-\mathrm{B} 6$ in the Van Heurck collection, Botanic Garden Meise) of the latter (Figs 31, 32) reveals however several differences that can be used to separate both taxa. Nitzschia commutata has a less linear valve outline but shows on the contrary more convex valve margins. In $N$. australocommutata, the valve margins hardly become convex between the valve center and the apices. The apices in $N$. commutata are also less protracted and show a more acutely rounded end. Although both taxa show a similar stria density (19-21 in $10 \mu \mathrm{m}$ in $N$. commutata), the striae in N. australocommutata are slightly coarser with discernible areolae in LM whereas in $N$. commutata the areolae are less visible in LM. Other comparable taxa include some taxa that are considered as synonyms of $N$. commutata. Nitzschia subamphioxoides Hust., described from Austria (Hustedt 1959), shows a similar valve outline but is much longer $(75-100 \mu \mathrm{m})$ and somewhat wider (6-7 $\mu \mathrm{m}$ ). Nitzschia pamirensis Hust. (formerly N. ostenfeldii VAN Heurck) has shorter, more sturdy valves with a higher stria density (up to 24 striae in $10 \mu \mathrm{m}$ ). It is possible that Nitzschia dubia var. australis Perag. could be conspecific but since the material collected by Peragallo is no longer available (M. Coste, IRSTEA Bordeaux, pers. comm.), it is impossible to revise this species.

\section{Nitzschia gracilis HANTzSCH (Figs 37-59)}

Light microscopy (Figs 37-55): Frustules with nitzschioid symmetry. In valve view, valves linear to linear-lanceolate with straight margins and long protracted, thin apiculate apices. Valve length $(n=50)$ : length 14-75 $\mu \mathrm{m}$, width 2-3 $\mu \mathrm{m}$. Striae not discernible in LM. Marginal fibulae very small, usually evenly spaced, 16-20 in $10 \mu \mathrm{m}$. Canal raphe eccentric. Raphe slit is continuous.

Scanning electron microscopy (Figs 56-59): Raphe continuous, situated on a keel on a hyaline area on border between the valve face and the mantle. External distal raphe endings hooked. Striae composed of rectangular to elliptical areolae with hymenate occlusions, ca. 55 in $10 \mu \mathrm{m}$. Virgae wider than vimines. Areolae small, evenly spaced throughout the valve, with the exception of one row of larger, rectangular areolae closest to the raphe on the keel, ca. 60-70 in $10 \mu \mathrm{m}$. Internally, areolae round. Internal distal raphe endings 

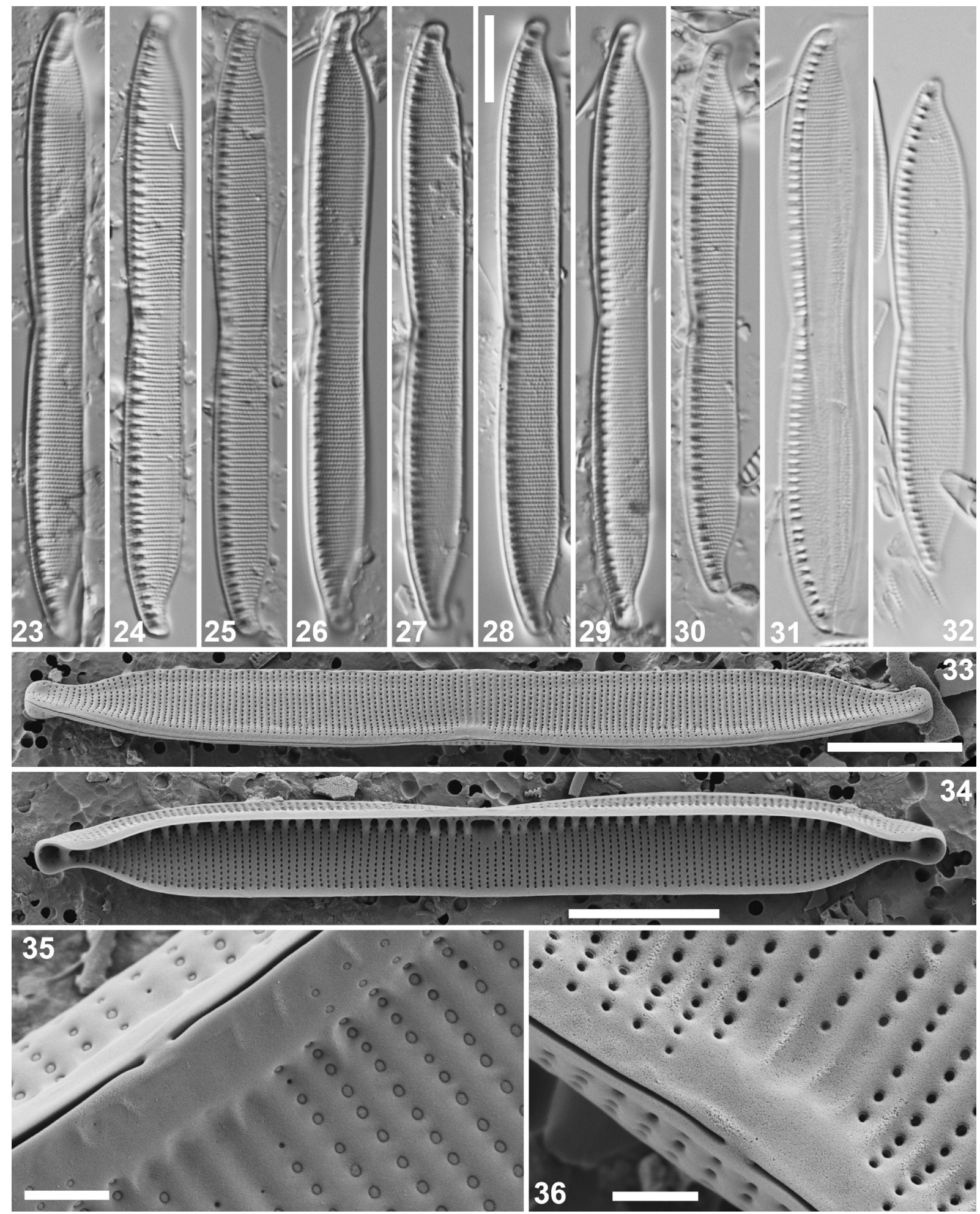

Figs 23-36. Nitzschia australocommutata sp. nov. (23-30,33-36) and N. commutata (31-32): LM. Pictures of N. australocommutata taken from the type population (Clearwater Lake 3, Clearwater Mesa, James Ross Island, sample CLW-D60, fig. 25 represents the holotype). Pictures of N. commutata taken from the lectotype slide (Coll. Van Heurck VI-48-B6) Single valves showing observed size range; (33) SEM. External whole valve view; (34) SEM. Interior whole valve view; (35) SEM. External detail of the central area in oblique view. Areolae with occlusions; (36) SEM. External detail of the central area. Areolae without occlusions. Scale bars $10 \mu \mathrm{m}(23-34) ; 1 \mu \mathrm{m}(35-36)$. 

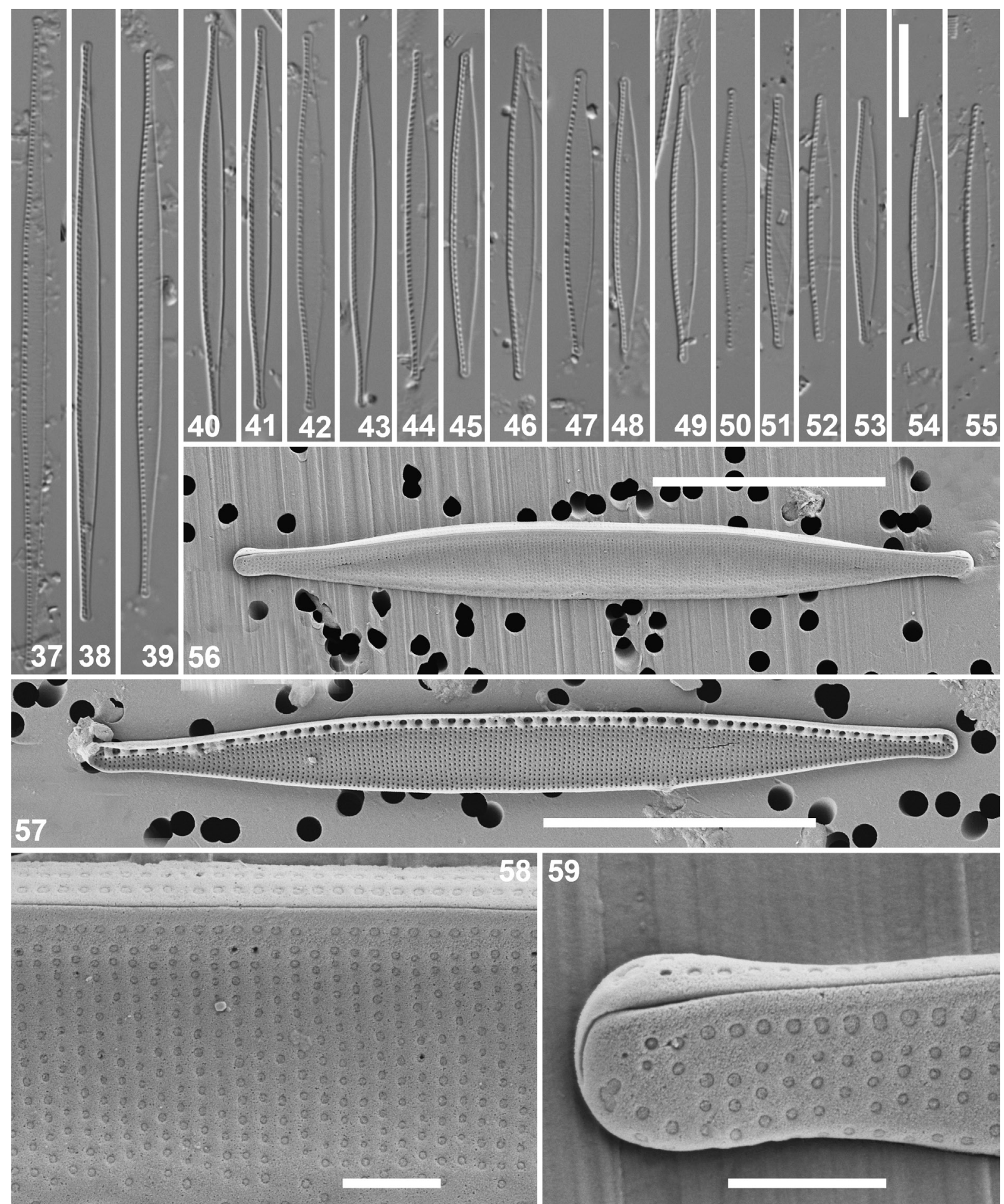

Figs 37-59. Nitzschia gracilis: (37-55) LM. Pictures taken from various populations in the Maritime Antarctic Region. Single valves showing observed size range; (56) SEM External whole valve view; (57) SEM. Interior whole valve view; (58) SEM. Detail of external valve showing occluded striae; (59) SEM. Detail of external valve showing hooked distal raphe end. Scale bars $10 \mu \mathrm{m}(37-57) ; 1 \mu \mathrm{m}(58-59)$.

terminating into helictoglossae prior to the hook of the external terminal fissure. Internally, canal raphe subtended by fibulae widening to the valve face to form round portulae. Fibulae evenly spaced throughout the valve, every 1-2 striae.

Ecology and Distribution: Nitzschia gracilis is a cos- mopolitan, widespread species and a very common species in the sub-Antarctic and Maritime Antarctic Regions (Kellogg \& Kellogg 2002). On Livingston Island (South Shetland Islands) and James Ross Island, it was often found dominantly in larger lakes, seepages and wet moss vegetation with populations exceeding occasionally $50 \%$ of the total number of counted val- 


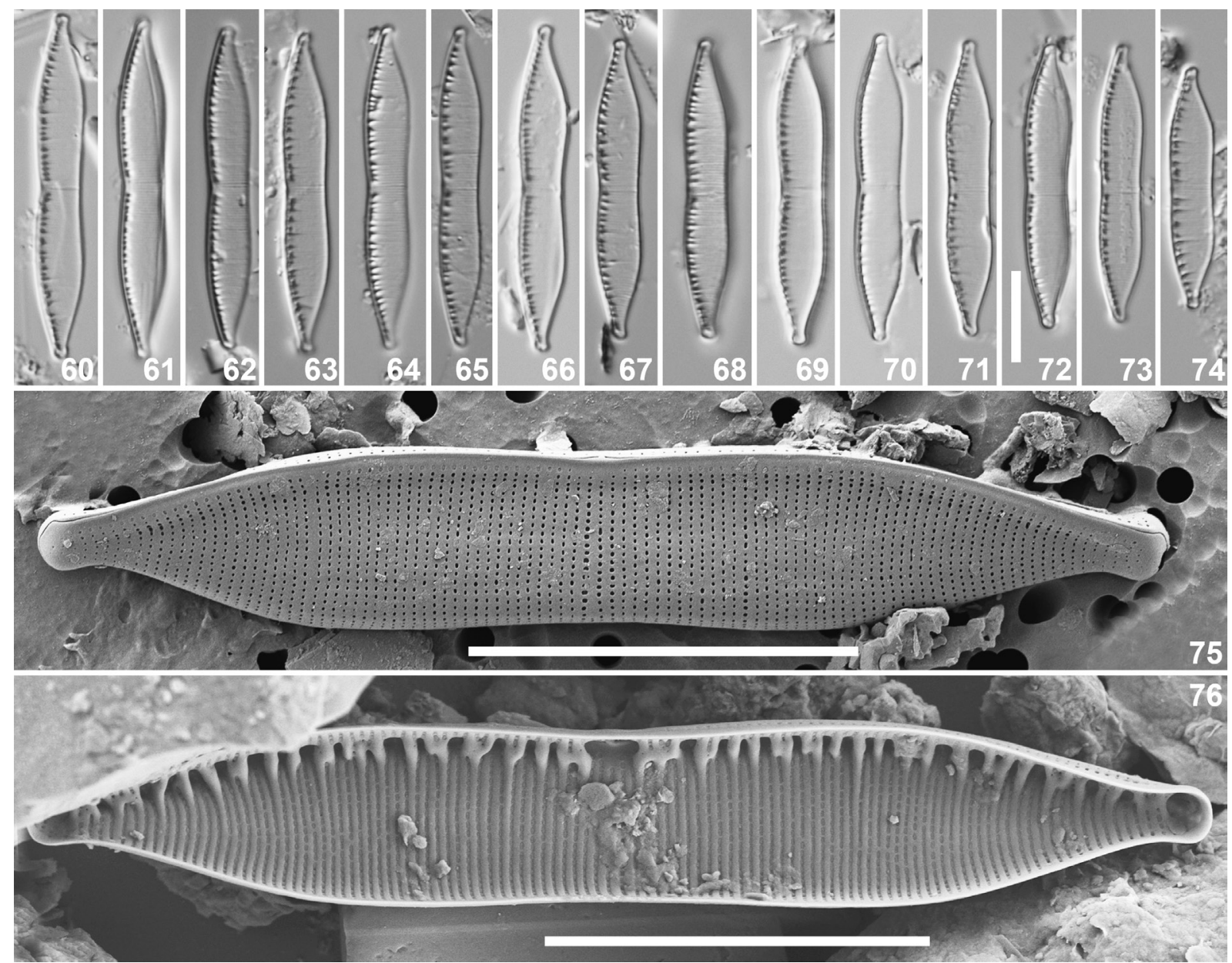

Figs 60-76. Nitzschia homburgiensis: (60-74) LM. Pictures taken from various populations in the Maritime Antarctic Region. Single valves showing observed size range; (75) SEM. External whole valve view; (76) SEM. Interior whole valve view. Scale bars $10 \mu \mathrm{m}$.

ves. On Nelson Island and King George Island (South Shetland Islands) $N$. gracilis was commonly observed in streams and brooks having a neutral to alkaline $\mathrm{pH}$ (7.0-9.9) and a low specific conductance value (76$\left.257 \mu \mathrm{S} . \mathrm{cm}^{-1}\right)$. A large population $(42 \%$ of the total number of counted valves) was found on a very wet rock among thin slimy mats on King George Island. Occasionally the species was found in soil.

Taxonomic Remarks: There are at present no SEM observations of the type material of Nitzschia gracilis available. Comparison with specimens on the slide of RABEnHOrst (Algen Europas 946) (VAN HeurCK-collection, IV-25-B8) shows no morphological difference with the Antarctic populations. The smallest specimens weakly resemble Nitzschia agnita Hust. but the latter shows more convex, instead of parallel margins and shorter, more acutely ending apices (KRAMMER \& LANGE-BERTALOT 1988).

\section{Nitzschia homburgiensis LANGE-BERTALOT (Figs 60-76)}

Light microscopy (Figs 60-74): Frustules with nitz- schioid symmetry. Valves linear in valve view and distinctly constricted at the center with narrowly rostrate, produced apices. Valve dimensions ( $n=25): 23-41 \mu \mathrm{m}$, width $4-5 \mu \mathrm{m}$. Striae almost not discernible in LM, only slightly visible with DIC or oblique lighting. Fibulae irregularly spaced, usually transapically elongated, variable in shape and size with a distinct central nodule, $10-14$ in $10 \mu \mathrm{m}$. Canal raphe eccentric. Raphe is not continuous.

Scanning electron microscopy (Figs 75-76): Raphe situated on a slightly raised keel between the valve face and the mantle. External proximal raphe endings curved, terminating in a simple pore. External distal raphe endings strongly hooked. Proximal raphe endings terminating in helictoglossae. Distal raphe ends terminating onto small helictoglossae prior to the hook of the external terminal fissure. Striae parallel at the valve center becoming convergent towards the apices and continuing from the valve face onto the mantle, ca. 38-40 in $10 \mu \mathrm{m}$. Striae composed of elliptical areolae evenly spaced throughout the valve. Virgae wider than vimines throughout the valve. One row of areolae closest to the raphe occluded by hymenes. Internally, 


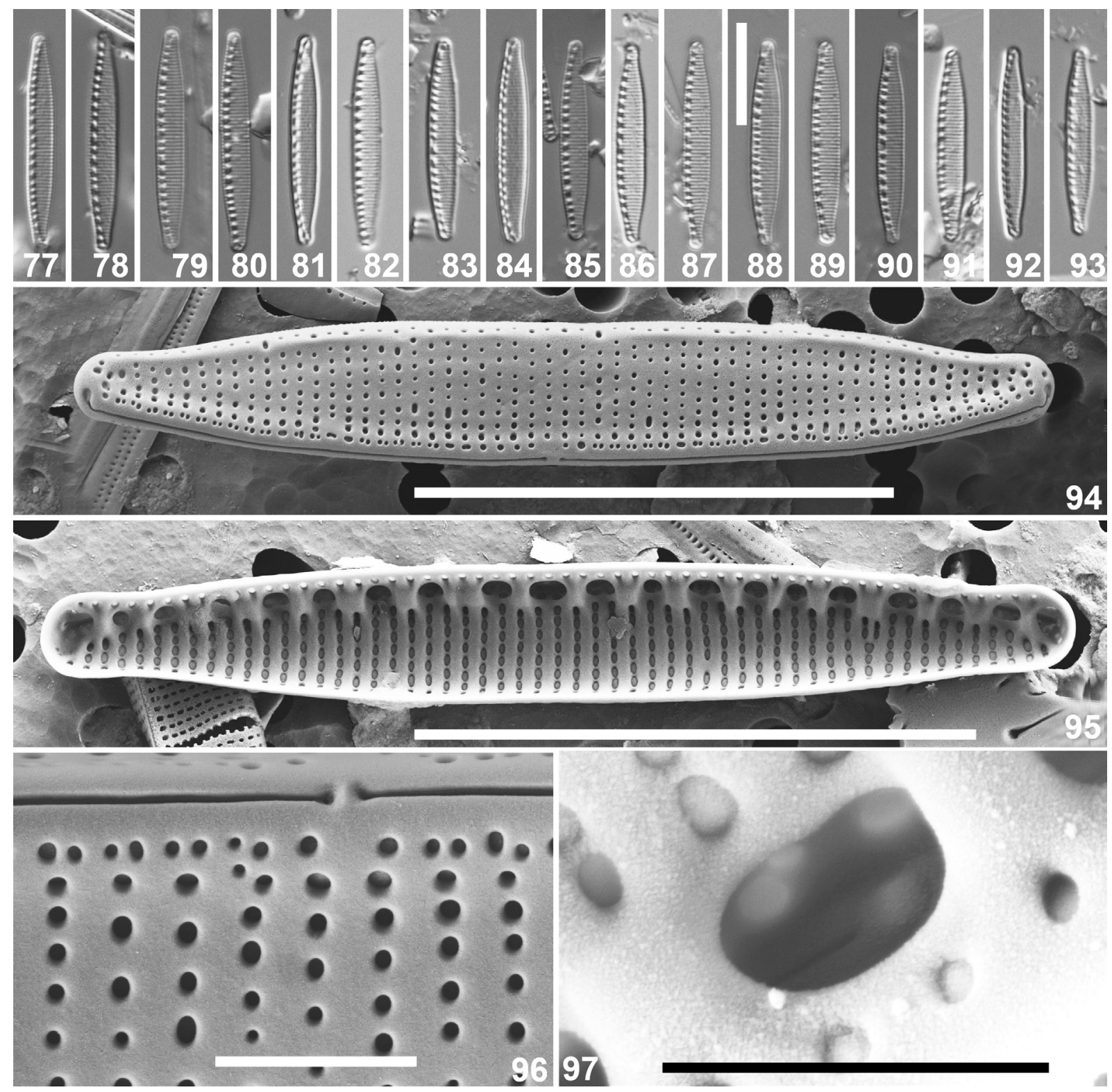

Figs 77-97. Nitzschia kleinteichiana sp. nov.: (77-93) LM. Pictures taken from the type population (Red Lake, Ulu Peninsula, James Ross Island, sample JRI-D28, fig. 89 represents the holotype). Single valves showing observed size range; (94) SEM. External whole valve view; (95) SEM. Interior whole valve view; (96) External valve showing detail of the proximal raphe ends; (97) Internal valve showing detail of the proximal raphe ends and occluded striae. Scale bars $10 \mu \mathrm{m}(77-95) ; 1 \mu \mathrm{m}(96-97)$.

canal raphe subtended by irregularly spaced, often merged fibulae. Portulae absent. Each fibula spaced for every 1-3 striae.

Ecology and Distribution: Nitzschia homburgiensis is a cosmopolitan and a very common diatom species in the entire Maritime Antarctic Region (KellogG \& KeLlOGg 2002 and references therein). The species has been observed in various terrestrial and aquatic habitats on James Ross Island and several islands of the South Shetland Archipelago (Dart Island, Deception Island, King George Island, Nelson Island and Livingston Island). Large populations of the species were observed on Livingston Island and James Ross Island in lakes, rivers, seepage areas and moss vegetation, often dominating the flora with relative abundances exceeding $50 \%$ of all counted diatoms (KopAlOvÁ \& VAN DE ViJver 2013; Kopalová et al. 2013).

Taxonomic remarks: Nitzschia homburgiensis was described in 1978 by LANGE-BERTALOT to separate it from the larger Nitzschia umbonata (EHRENB.) LANGEBERT. Careful comparison between the morphology of the Antarctic population and the description and illustrations in LANGE-BERTALOT (1978) revealed no significant differences, confirming the identification of the former as $N$. homburgiensis. Valves can however be somewhat smaller than the type population as the original description mentions $32-52 \mu \mathrm{m}$ whereas the Antarctic populations range from 23 to $41 \mu \mathrm{m}$. 


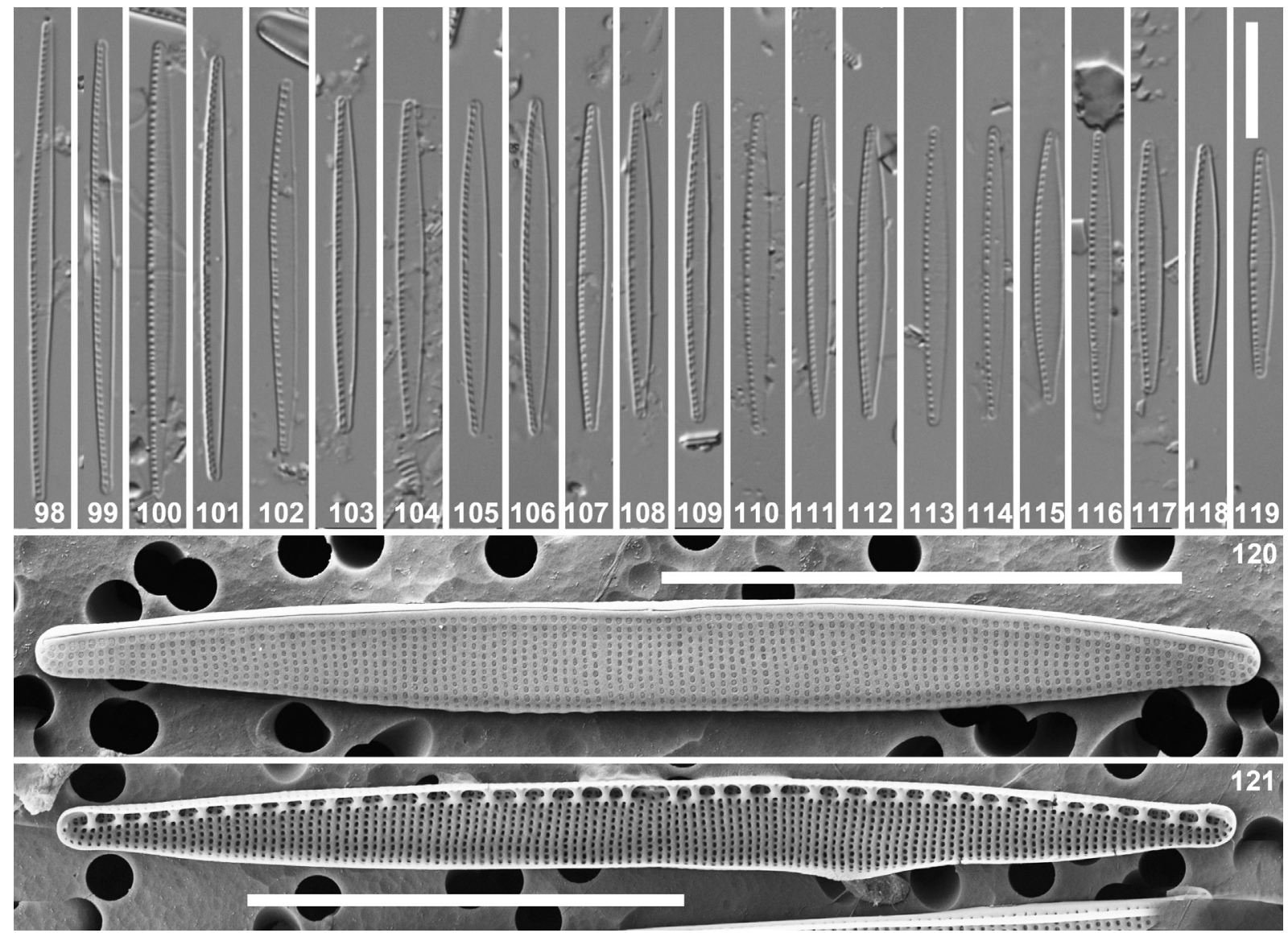

Figs 98-121. Nitzschia paleacea: (98-120) LM. Pictures taken from various populations in the Maritime Antarctic Region. Single valves showing observed size range; (120) SEM. External whole valve view; (121) SEM. Interior whole valve view. Scale bars $10 \mu \mathrm{m}$.

\section{Nitzschia kleinteichiana sp. nov. (Figs 77-97)}

\section{Description}

Light Microscopy (Figs 77-93): Frustules with nitzschioid symmetry. Valves linear to narrowly lanceolate in valve view, with rostrate to cuneate, protracted apices. Valve dimensions $(\mathrm{n}=50)$ : length $18-23 \mu \mathrm{m}$, width 2-3 $\mu \mathrm{m}$. Striae weakly, but visibly punctate, parallel at the valve center becoming slightly convergent towards the apices, $27-30$ in $10 \mu \mathrm{m}$. Fibulae evenly spaced, except for the distinct central nodule, $11-13$ in $10 \mu \mathrm{m}$. Canal raphe eccentric, raised on a keel above the surface of the valve. Raphe slit not continuous.

Scanning electron microscopy (Figs 94-97): Raphe situated on the border of the valve face and the mantle, raised on a keel above the surface of the valve. Narrow hyaline marginal ridge opposite the raphe. Striae uniseriate, evenly spaced throughout the valve, composed of small, elliptical to round areolae. Each stria on the valve face and mantle terminating on either side of the raphe in 1-2 series of mostly 2 , rarely 1 , smaller, round areolae. Virgae slightly thicker than vimines, especially closest to the raphe. Areolae with hymenate occlusions, positioned medially and best seen from the inside of the valve. External proximal raphe endings termi- nating in a simple pore, weakly deflected. External distal raphe endings strongly hooked, terminating in an expanded opening. Internal distal raphe ends terminating in helictoglossae prior to the hook of the external terminal fissure. Internally, canal raphe subtended by fibulae widening to the valve face to form round to elliptical portulae, with a slightly larger portula near the proximal raphe endings. Fibulae of varying widths, every 1-2 striae.

Holotype: BR-4411 (Botanic Garden Meise, Belgium), fig. 89 represents the holotype.

Isotypes: PLP-282 (University of Antwerp, Belgium), BRM-ZU10/22 (HustedT Collection, Bremerhaven, Germany).

Type locality: Red Lake, Ulu Peninsula, James Ross Island, sample JRI-D28 $\left(63^{\circ} 54^{\prime} 33.3^{\prime \prime} \mathrm{S}, 57^{\circ} 47^{\prime} 46.3^{\prime \prime}\right.$ W) (Leg. L. NedBalovÁ), coll. date 22/02/2008).

Etymology: The species is named after Dr. JULIA KLEINTEICH (Université de Liège), member of the CCAMBIO project team.

Ecology and distribution: The species was likely reported in the past as Nitzschia perminuta or N. frustulum making the exact distribution of $N$. kleinteichiana at present not entirely known. The species was the most 

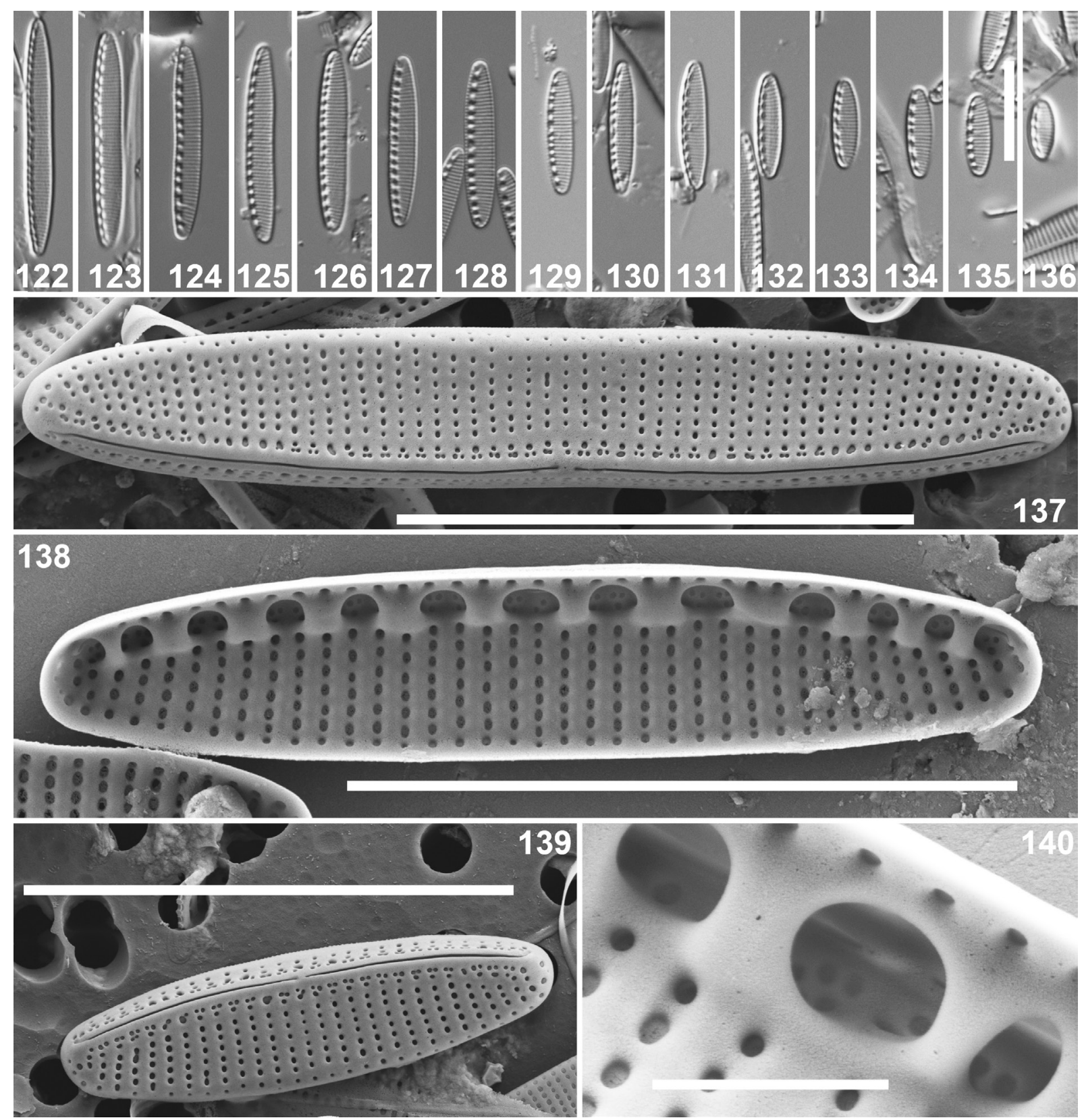

Figs 122-140. Nitzschia soratensis: (122-136) LM. Pictures taken from various populations in the Maritime Antarctic Region. Single valves showing observed size range; $(138,139)$ SEM. External whole valve view; (138) SEM. Interior whole valve view; (140) Internal valve showing detail of proximal raphe ends. Scale bars $10 \mu \mathrm{m}(122-139) ; 1 \mu \mathrm{m}(140)$.

common of the three taxa in the N. perminuta complex that were separated and often dominating the flora. It shows a broad ecological amplitude and was found in lakes, ponds, rivers, seepage areas and mosses.

Taxonomical remarks: Nitzschia kleinteichiana is morphologically similar to $N$. velazqueziana $\mathrm{sp}$. nov. and $N$. annewillemsiana. Nitzschia annewillemsiana differs with more convex valve margins, broader valves (3-4 vs. $2-3 \mu \mathrm{m})$ and a lower stria density (24-26 vs. $27-30$ in $10 \mu \mathrm{m}$ ), and lacks the typical protracted, rostrate apices of $N$. kleinteichiana. Nitzschia velazqueziana shares the same valve outline with rostrate apices and almost parallel, only weakly convex margins (different from $N$. annewillemsiana). The main difference between $N$. velazqueziana and N. kleintechiana, clearly visible in LM, can be found in the stria density: $24-25$ vs. $27-30$ in $10 \mu \mathrm{m}$, respectively). In the SEM, $N$. velazqueziana has a continuous raphe externally whereas in N. kleinteichiana, separated proximal raphe endings can be seen. The same structure is also found in $N$. soratensis but the latter can be separated based on a different valve outline, with non-protracted, broadly rounded apices. Nitzschia acidoclinata has a quite developed central nodule, visible in a very clear gap in the fibulae near the valve center, making 

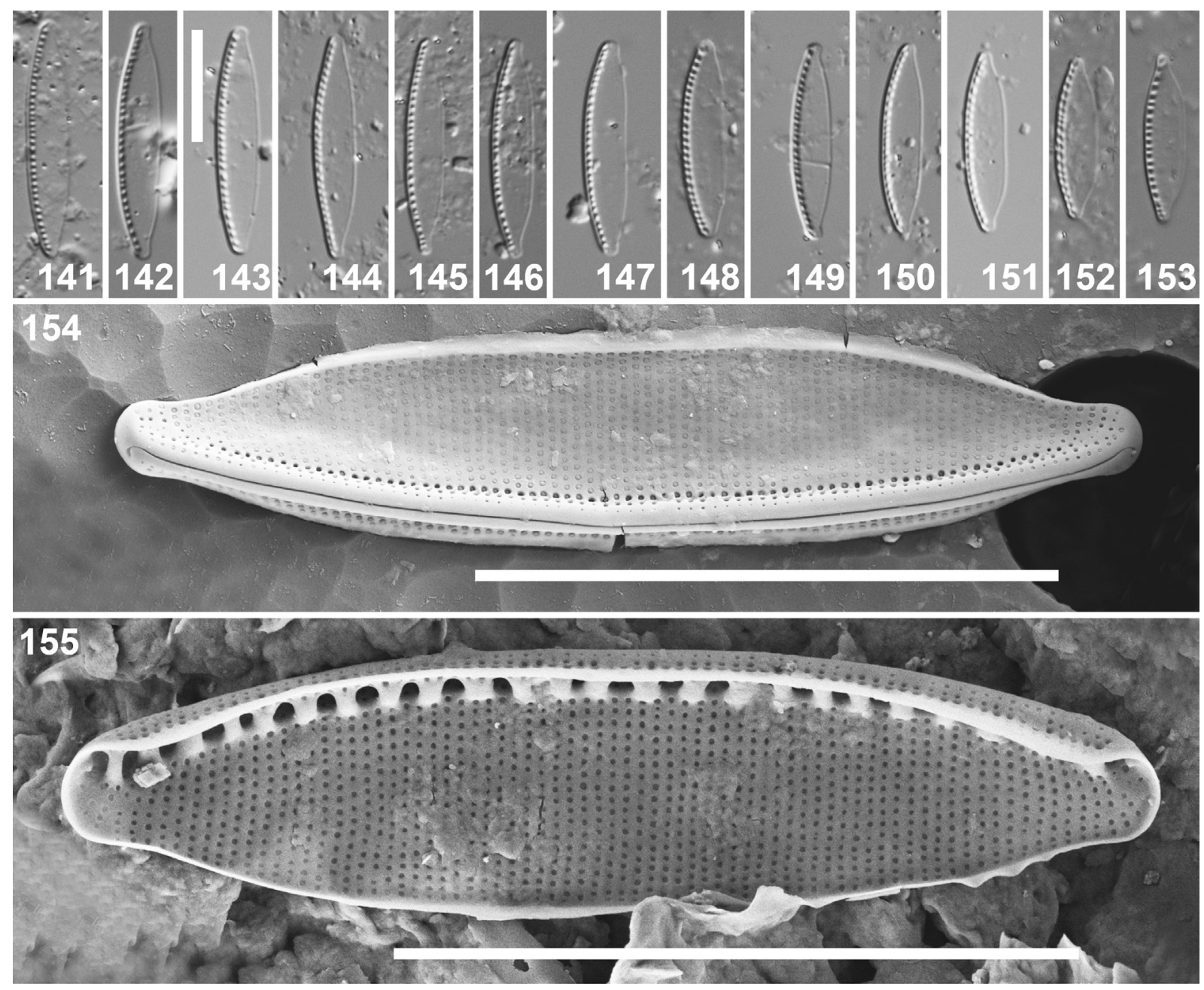

Figs 141-155. Nitzschia stelmachpessiana sp. nov.: (141-153) LM. Pictures taken from the type population (soil near Muddy Lake, Ulu Peninsula, James Ross Island, sample JRI-D18, fig. 143 represents the holotype). Single valves showing observed size range; (154) SEM. External whole valve view; (155) SEM. Interior whole valve view. Scale bars $10 \mu \mathrm{m}$.

all conspecificity between the latter and both $N$. velazqueziana and $N$. kleinteichiana unlikely. Most similar however is the complex of species around N. perminu$\mathrm{ta}$. The ultrastructure of the type of $N$. perminuta is at present unclear. Krammer \& LANGE-Bertalot (1988) published two pictures of the type material (plate 72, figs 1-2A). These two valves show broader, linearlanceolate valves than $N$. kleinteichiana with typically convex margins and clearly protracted apices and a stria density of ca. 30 in $10 \mu \mathrm{m}$. According to ANTONIADES et al. (2008), N. perminuta shows a continuous external raphe, contrary to $N$. kleinteichiana that has clear external proximal raphe endings. These features all exclude conspecificity.

\section{Nitzschia paleacea Grunow (Figs 98-121)}

Light microscopy (Figs 98-119): Frustules with nitzschioid symmetry. Valves linear to narrowly lanceolate in valve view with narrowly rounded apices. Valve dimensions $(n=20)$ : length $17-46 \mu \mathrm{m}$, width $1.5-2.5 \mu \mathrm{m}$. Striae very fine, not discernible in LM. Fibulae evenly spaced, except for a distinct central nodule where fibulae show a distinct gap in the middle, 17-20 in $10 \mu \mathrm{m}$. Canal raphe eccentric, raised on a slight keel above the valve surface. Raphe slit not continuous.

Scanning electron microscopy (Figs 120-121): Raphe situated on a slight keel, positioned on the junction between valve face and mantle. External proximal raphe endings close together, terminating in a simple pore. External distal raphe fissures strongly hooked. Internal proximal raphe endings terminating straight and not enlarged. Clear central nodule present between the proximal endings. Striae parallel throughout the valve, mostly composed of evenly spaced elliptical to round areolae, ca. 54 in $10 \mu \mathrm{m}$. Striae continuing from the valve face onto the keel. Virgae wider and thicker than vimines throughout the valve. Areolae externally occluded by perforated hymenes. Internal distal raphe ends terminating in helictoglossae prior to the hook of the external terminal fissure. Internally, canal raphe subtended by fibulae widening to the valve face to form round to elliptical portulae, with a larger 

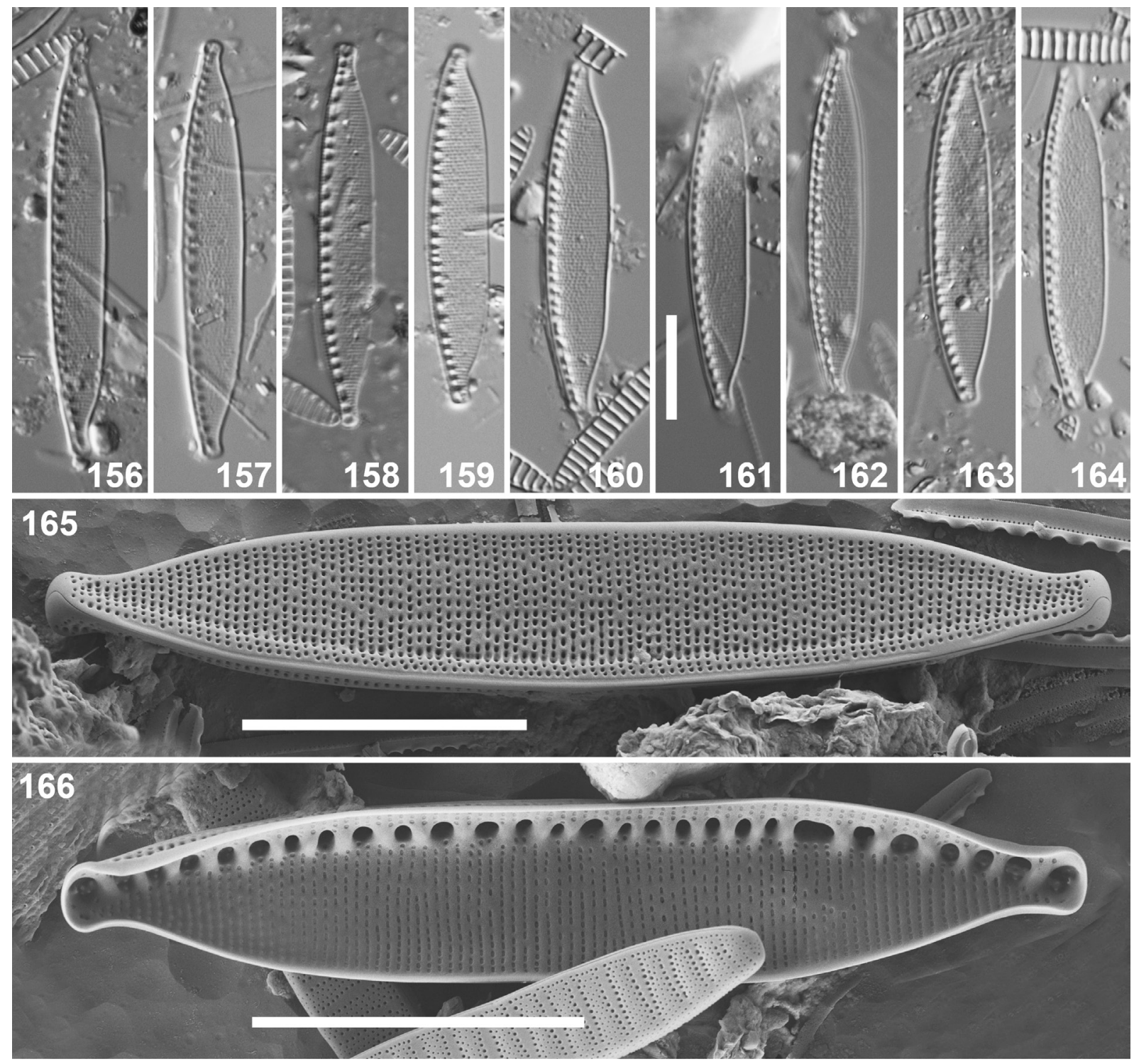

Figs 156-166. Nitzschia vancauwenbergiana sp. nov.: (156-164) LM. Pictures taken from the type population (Clearwater Lake 4, Clearwater Mesa, James Ross Island, sample CLW-D62, fig. 157 represents the holotype). Single valves showing observed size range; (165) SEM. External whole valve view; (166) SEM. Interior whole valve view. Scale bars $10 \mu \mathrm{m}$.

portula surrounding the proximal raphe ends. Fibulae evenly spaced throughout the valve, located on every $1-4$ striae.

Ecology and distribution: Nitzschia paleacea is a very common, cosmopolitan species that has been reported from a large number of Maritime and sub-Antarctic localities. Kellogg \& Kellogg (2002) list several records from the South Shetland Islands and the South Orkney Islands. The largest populations of the species were found on Livingston Island and James Ross Island, often with relative abundances exceeding $40 \%$ of all counted diatoms (Kopalová \& VAN DE ViJVER 2013; Kopaloví et al. 2013). The species was observed in lakes, rivers, seepage areas and wet moss vegetation.

Taxonomic remarks: The morphology of the An- tarctic populations shows almost no differences with the type specimens of $N$. paleacea represented in KRAMMER \& LANGE-BerTalot (1988: plate 81, figs 2, 3) and hence conspecificity is more than likely. The species is very characteristic by the typical gap in the fibulae near the valve center and the very high density of striae in $10 \mu \mathrm{m}$.

\section{Nitzschia soratensis E.A.Morales et M.L.Vis (Figs 122-140)}

Light microscopy (Figs 122-136): Frustules with nitzschioid symmetry. In valve view, valves linear to linear-elliptical with almost parallel margins and nonprotracted, narrowly to moderately broadly rounded apices. Valve dimensions $(\mathrm{n}=25)$ : length $6-24 \mu \mathrm{m}$, width 2.5-3.0 $\mu \mathrm{m}$. Striae, often punctate in LM, parallel 


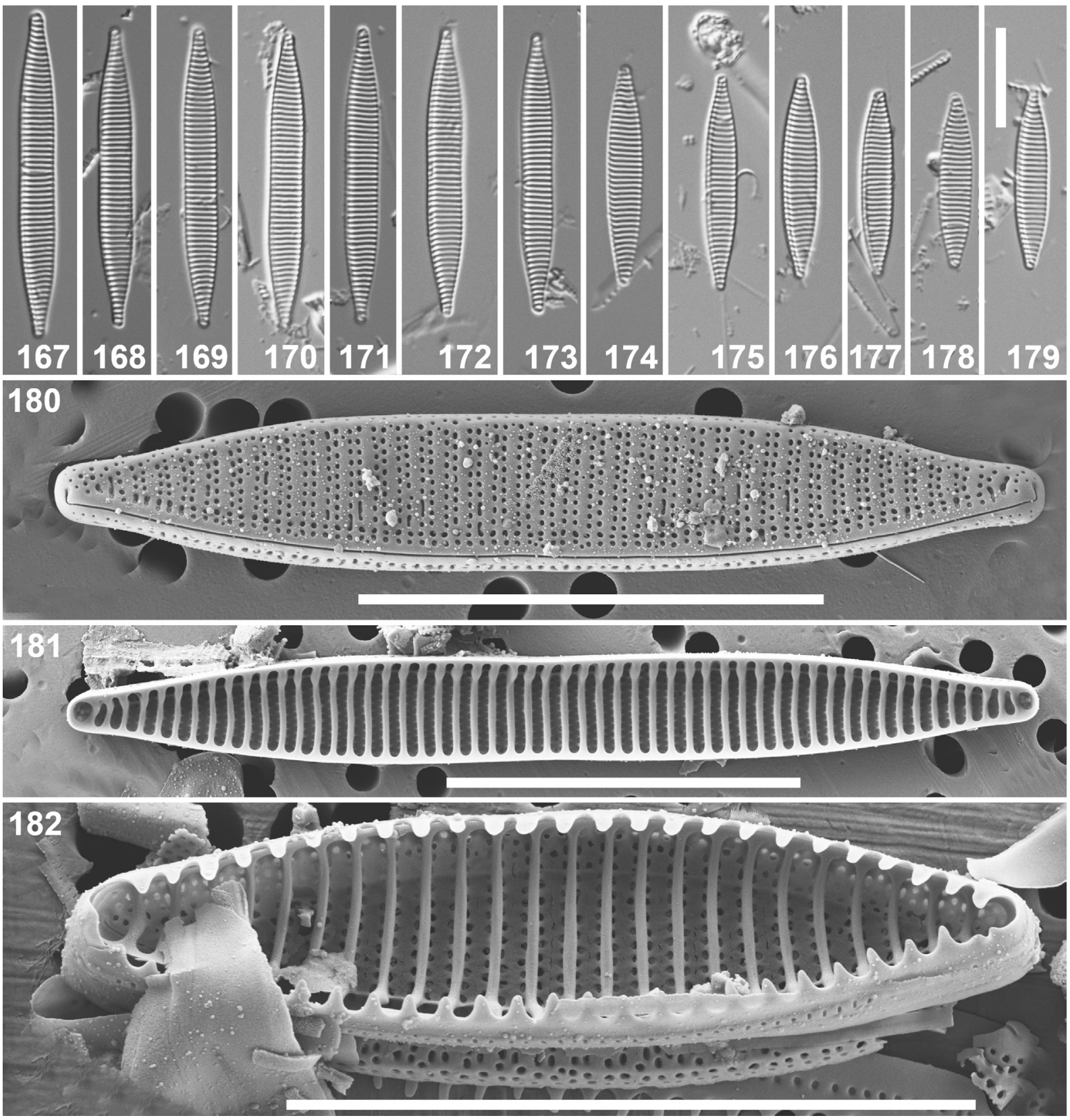

Figs 167-182. Nitzschia vandeputteana sp. nov.: (167-179) LM. Pictures taken from the type population (Dart Island (King George Island area), South Shetland Islands, sample DAR4, fig. 168 represents the holotype). Single valves showing observed size range; (180) SEM. External whole valve view; (181) SEM. Interior whole valve view; (182) SEM. Interior whole valve view showing attached valvocopula with scalloped extensions that meet up with the fibulae. Fibulae extend across the face of the valve. Scale bars $10 \mu \mathrm{m}$.

near the valve center becoming convergent towards the apices, 28-30 in $10 \mu \mathrm{m}$. Fibulae evenly spaced but of varying widths, 11-12 in $10 \mu \mathrm{m}$. Central nodule present. Canal raphe eccentric. Raphe slit not continuous.

Scanning electron microscopy (Figs 137-140): Raphe situated eccentrically between the valve face and the mantle. External proximal raphe endings almost straight, terminating in a simple pore. External distal raphe fissures short, weakly hooked towards the mantle, terminating on the mantle before the apex of the valve. Proximal raphe endings terminating on a distinct central nodule. Distal raphe endings terminating in helictoglossae prior to the hook of the external terminal fissure. Striae evenly spaced throughout the valve, composed of small, elliptical to round areolae. Striae on valve mantle and valve face terminating in two smaller areolae located next to the raphe forming, together with one isolated areola per stria a triplet. Occasionally, areolae in the triplet fused together to form one large areola. Virgae wider and thicker than vimines throughout the valve. Internally, round areolae occluded by medially-placed hymenes. Internally, canal raphe subtended by fibulae widening to the valve 

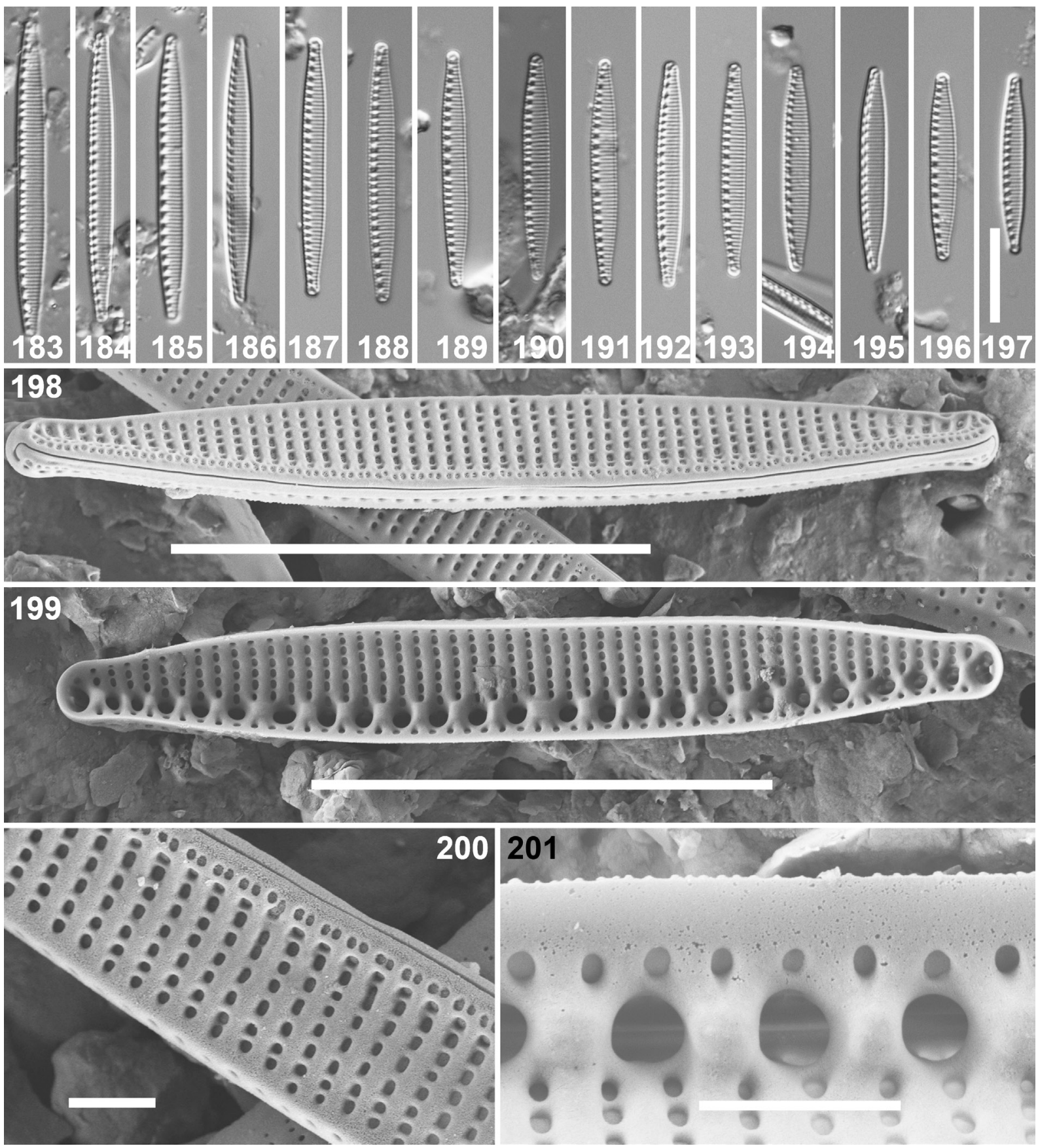

Figs 183-201. Nitzschia velazqueziana sp. nov.: (183-197) LM. Pictures taken from the type population (Katia Lake II, Ulu Peninsula, James Ross Island, sample JRI-D14, fig. 187 represents the holotype). Single valves showing observed size range; (198) SEM. External whole valve view; (199) SEM. Interior whole valve view; (200) External valve showing detail of elliptical areolae; (201) Internal valve showing detail of fibulae and occluded areolae. Scale bars $10 \mu \mathrm{m}(183-199) ; 1 \mu \mathrm{m}(200-201)$.

face to form round to elliptical portulae, with a slightly larger portula surrounding the proximal raphe ends. Fibulae evenly spaced throughout the valve, separated by $1-2$ striae.

Ecology and Distribution: Nitzschia soratensis is a common, though never dominant $(<15 \%)$, constituent of the diatom flora in lakes and pools of the Maritime Antarctic Region. So far the species has been confirmed from Livingston Island (i.e. Zidarova 2008, as
$N$. inconspicua), King George Island and James Ross Island. On James Ross Island, several larger populations were found in alkaline lakes $(\mathrm{pH}$ 7.7-8.8) with a moderate conductivity (200-400 $\left.\mu \mathrm{S} . \mathrm{cm}^{-1}\right)$. On King George Island (South Shetland Islands) only small populations were observed in small ponds and streams with slightly alkaline $\mathrm{pH}$ (7.8) and low conductivity (118-200 $\mu$ S.cm-1).

Taxonomic remarks: The Antarctic populations of 


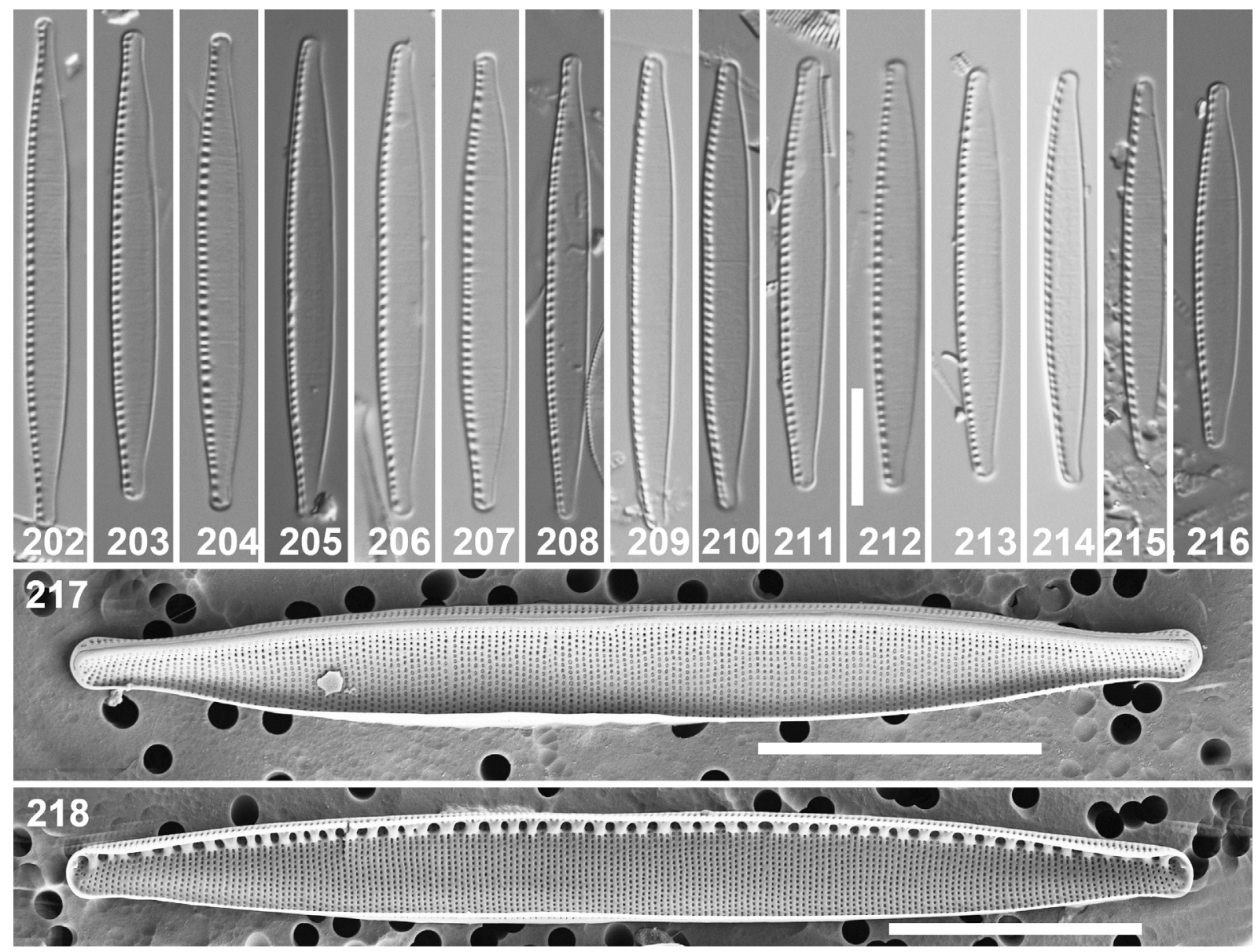

Figs 202-218. Nitzschia wilmotteana sp. nov.: (202-216) LM. Pictures taken from the type population (Noodle Lake, Clearwater Mesa, James Ross Island, sample JRI-D63, fig. 206 represents the holotype). Single valves showing observed size range; (217) SEM. External whole valve view; (218) SEM. Interior whole valve view. Scale bars $10 \mu \mathrm{m}$.

Nitzschia soratensis show almost no morphological differences with the type material from Bolivia (MoRALES \& Vis 2007; Trobajo et al. 2013) and are therefore considered conspecific. The species was often reported in the Antarctic literature as $N$. inconspicua (e.g., BJöRCK et al. 1996; VINOCUR \& UNREIN 2000, ZIDAROVA 2008), but it was recently split off based on its ultrastructure and ecological preferences (TROBAJO et al. 2013). The two taxa differ in their stria structure: Nitzschia inconspicua possesses striae that do not terminate in a double row of areolae close to the raphe, contrary to $N$. soratensis that clearly shows a doubling of the areolae near the raphe (LANGE-BERTALOT 1977; TrobAjo et al. 2013).

\section{Nitzschia stelmachpessiana sp. nov. (Figs 141-155)}

\section{Description}

LM morphology (Figs 141-153): Frustules with nitzschioid symmetry. Valves in valve view broadly lanceolate with acutely ending, rostrate apices, weakly curved backwards. Valve margins clearly asymmetric with one (fibulae-bearing side) convex margin and one with a clear narrowing close to the apices. Valve dimensions $(\mathrm{n}=15)$ : length $14.5-21.0 \mu \mathrm{m}$, width 3-4 $\mu \mathrm{m}$. Striae not discernible in LM. Canal raphe eccentric, raised on a keel. Raphe slit is continuous. Fibulae short, almost quadrangular, evenly spaced, $15-17$ in 10 $\mu \mathrm{m}$.

SEM microscopy (Figs 154-155): Raphe situated on a keel, eccentrically positioned on the border between the valve face and the mantle (Fig. 152). Opposite the raphe, a hyaline marginal ridge present. External proximal endings straight, simple. External distal raphe endings hooked. Internal distal raphe endings terminating in small helictoglossae positioned on the mantle. Striae parallel in the valve center becoming convergent towards to the apices. Striae composed of evenly spaced, small, round areolae with a row of smaller areolae closest to the raphe, ca. 52 in $10 \mu \mathrm{m}$. Virgae only slightly wider than vimines. Areolae externally occluded by hymenes. Internally, canal raphe subtended by fibulae widening to the valve face to form round portulae. Fibulae almost evenly spaced throughout the valve, every 1-2 striae.

Holotype: BR-4412 (Botanic Garden Meise, Belgi- 
um), fig. 143 represents the holotype specimen.

Isotypes: PLP-283 (University of Antwerp, Belgium), BRM-ZU10/23 (HustedT Collection, Bremerhaven, Germany).

Type locality: soil near Muddy Lake, Ulu Peninsula, James Ross Island, sample JRI-D18 (6351'50.1" S, 5757'12.2"W) (Leg. L. NedBalová), coll. date 01/02/2008).

Etymology: the species is named after Mr. IGOR STELMACH Pessi, member of the CCAMBIO-project.

Ecology and distribution: Nitzschia stelmachpessia$n a$ was found in only one sample taken from soil near Muddy Lake on James Ross Island. The soil was covered with salt precipitates. Single valves were also observed on Livingston Island (ZIDAROVA, pers. obs.). However, it is possible that some of the records of $N$. pusilla Grunow listed in KellogG \& Kellogg (2002) for the Maritime Antarctic Region represent N. stelmachpessiana.

Taxonomic remarks: The most similar species to Nitzschia stelmachpessiana is N. pusilla. KRAMMER \& LANGE-BERTALOT (1988, plate 79, figs 16-28) show several valves from brackish environments that could be associated to $N$. pusilla but are probably not conspecific (Krammer \& Lange-Bertalot 1988). Nitzschia stelmachpessiana can however be discriminated by differences in valve outline. Contrary to N. pusilla, N. stelmachpessiana shows less symmetry in valve margins with a less convex margin on the side lacking the fibulae and a more rounded margin on the fibulae-bearing side. The fibulae-lacking side shows in many specimens of $N$. stelmachpessiana a typical narrowing just below the apices, a feature absent in N. pusilla. The apices in $N$. stelmachpessiana are also more protracted and narrower than in N. pusilla. Nitzschia retusa LANGE-BERT. \& BONIK, often considered to be a synonym of $N$. pusilla, can be distinguished by more obtusely rounded apices (LANGE-BERTALOT \& BONIK 1976). Some valves identified in TroBAJo et al. (2009) show a striation density of ca. 48 in $10 \mu \mathrm{m}$ but can always be separated based on the more regularly spaced fibulae in N. stelmachpessiana whereas N. palea typically presents a very irregular fibula pattern.

Nitzschia vancauwenberghiana sp. nov. (Figs 156166)

\section{Description}

Light microscopy (Figs 156-164): Frustules with nitzschioid symmetry. Valves broad, lanceolate in valve view, with straight although sometimes constricted margins. Apices apiculate, clearly protracted. Valve dimensions $(n=15)$ : length 31-35 $\mu \mathrm{m}$, width 5-6 $\mu \mathrm{m}$. Striae clearly visible in LM, punctate, parallel throughout the entire valve, 30-32 in $10 \mu \mathrm{m}$. Fibulae transapically elongated, evenly spaced, $9-10$ in $10 \mu \mathrm{m}$. Canal raphe eccentric. Raphe slit continuous.

Scanning electron microscopy (Figs 165-166): Continuous raphe situated on a keel between the valve face and the mantle. Narrow hyaline marginal ridge present opposite the raphe. External distal raphe fissures strongly hooked. Striae composed of irregularly spaced elliptical to round, rather large areolae, extending from the valve face onto the keel and the mantle. Virgae slightly wider and thicker than vimines, especially close to the raphe. Areolae internally occluded by hymenes (Fig. 166). Internally, canal raphe subtended by fibulae. Fibulae evenly spaced throughout the valve, separated by $2-3$ striae.

Holotype: BR-4413 (Botanic Garden Meise, Belgium), fig. 157 represents the holotype specimen.

Isotypes: PLP-284 (University of Antwerp, Belgium), BRM-ZU10/25 (Hustedt Collection, Bremerhaven, Germany).

Type locality: Clearwater Lake 4, Clearwater Mesa, James Ross Island, sample CLW-D62 (6401'58.0" S, 5743'40.7"W) (Leg. L. NedBalová); coll. date 10/02/2009).

Etymology: the species is named after Mrs. MAAIKE VAn CAuwenberghe (BELSPO) to thank her for all her efforts regarding the CCAMBIO project.

Ecology and distribution: Nitzschia vancauwenberghiana was only found in several samples on Clearwater Mesa (James Ross Island). The largest population was found in Clearwater Lake 4, an alkaline lake $(\mathrm{pH}$ $8.5)$ with a high conductivity $\left(4000 \mu \mathrm{S} . \mathrm{cm}^{-1}\right)$. The sample was dominated by Denticula jamesrossensis VAN DE VIJVER et al.

Taxonomic remarks: The irregular spacing of the areolae within the striae, clearly visible in LM, gives this new species a very characteristic look that is only found in a few Nitzschia species worldwide. Nitzschia sigma (KüTz.) W.SмIтн is much larger with a different valve outline showing elongated, acute apices. The most similar taxa are however $N$. vitrea G. NORMAN and its variety salinarum GRUNOw. Both are however much larger with a valve width up to $14 \mu \mathrm{m}$ with a lower striae density (24-25 vs. 30-32 in $10 \mu \mathrm{m}$ in $N$. vancauwenberghiana) making conspecificity unlikely (Krammer \& LANGe-Bertalot 1988).

\section{Nitzschia vandeputteana sp. nov. (Figs 167-182)}

\section{Description}

Light microscopy (Figs 167-179): Frustules with nitzschioid symmetry. Valves linear to narrowly lanceolate, with straight to slightly concave margins and clearly protracted, rostrate apices in longer specimens, only weakly protracted, cuneately ending apices in smaller valves. Valve dimensions $(n=25)$ : length $17-32$ 
$\mu \mathrm{m}$, width 3-4 $\mu \mathrm{m}$. Striae with a rather thick appearance, parallel at the valve center becoming slightly convergent towards the apices, 18-20 in $10 \mu \mathrm{m}$. Fibulae hardly discernible in LM, located at the end of each interstria. Canal raphe eccentric, not raised on a keel. Raphe slit continuous.

Scanning electron microscopy (Figs 180-182): Continuous raphe situated on the junction between the valve face and the mantle. Keel absent. The raphe canal is embedded in the valve at the valve face-mantle junction, rather than being raised on a keel (contrast for example, N. vancauwenbergiana: Fig. 165). External distal raphe fissures hooked. Striae biseriate, evenly spaced throughout the entire valve, composed of round areolae. Near the raphe, areolae equidistantly arranged in two apically running series. Virgae wider than vimines throughout the valve. Internally, each virga bears a fibula. Canal raphe subtended by short fibulae that widen slightly towards the valve face, continuous with, and of equal number to, the virgae. Portulae absent. Valvocopula an open band with a single row of areolae and scalloped extensions that meet up with each of the fibulae (Fig. 182).

Holotype: BR-4414 (Botanic Garden Meise, Belgium), fig. 168 represents the holotype specimen.

Isotypes: PLP-285 (University of Antwerp, Belgium), BRM-ZU10/24 (Hustedt Collection, Bremerhaven, Germany).

Type locality: Dart Island (King George Island area), South Shetland Islands, sample DAR4 (62 13 ' 55.8', $\left.\mathrm{S}, 59^{\circ} 00^{\prime} 34.5^{\prime} \mathrm{W}\right)$ (Leg. R. Zidarova); coll. date 20/02/2013).

Etymology: The species is named after DR. ANTON VANDEPUTTE, member of the CCAMBIO-project.

Ecology and distribution: So far the species has only been found in one sample collected from Dart Island, the latter located in the Fildes strait between King George Island and Nelson Island. The sample was taken from the bottom of a shallow coastal half-frozen pool covered by thick cyanobacterial mats. The pool had an alkaline $\mathrm{pH}$ (9.4) and a moderately high conductivity value $\left(574 \mu \mathrm{S} . \mathrm{cm}^{-1}\right)$. Other diatom taxa present in the sample included Staurosira pottiezii VAN DE VIJVER, Stauroforma exuguiformis (LANGE-BERT.) FLower et al. and N. wilmottiana sp. nov.

Taxonomical remarks: The taxonomic position of Nitzschia vandeputteana is at present not entirely clear as the species shows morphological features of several nitzschioid genera: Nitzschia, Denticula, Fragilariopsis and Pseudo-nitzschia, the latter two genera being exclusively marine. The structure of the raphe is typical for the genus Nitzschia and Denticula. Fragilariopsis has short external distal raphe endings, always lacking distal fissures, whereas these are common in the genus Nitzschia. It never forms Pseudo-nitzschiatype colonies, which HASLE (1994) considered to be one of the key features of the latter genus (although some non-colonial species have been observed since 1994). The valve outline of $N$. vandeputteana has also never been observed within the genera Pseudonitzschia and Fragilariopsis. The structure of the striae is on the other hand a feature that is shared with many Pseudo-nitzschia taxa. Contradicting its position within Nitzschia is also the presence of the thickened transapical ribs giving the impressions that the fibulae extend across the entire transapical axis. This is often found within the genera Denticula, Pseudo-nitzschia and Fragilariopsis but seems absent within the genus Nitzschia. Denticula rainierensis SovereIGN and D. subtilis GRUNOw, weakly resemble $N$. vandeputteana, but both are smaller $(7-20 \mu \mathrm{m})$, multi- instead of biseriate, and are common in hot or warm springs and estuaries (HAMSHER et al. 2014). Although probably preliminary, the placement of this species in the genus Nitzschia seems at present the most acceptable, despite the genus Nitzschia not being monophyletic as currently circumscribed (LUNDHOLM et al. 2002; RIMET et al. 2011).

Several Nitzschia taxa show some resemblance to $N$. vandeputteana. Nitzschia westiorum, one of the only Nitzschia taxa present on the Antarctic Continent, shows a different external surface structure with raised ribs between the striae, a feature never observed in $N$. vandeputteana. Moreover, $N$. westiorum has a lower number of striae (14-16 vs 18-20 in $10 \mu \mathrm{m})$ and rostrate to capitate-produced apices (VAN DE VIJVER et al. 2012). Nitzschia angustatula LANGE-BERT. has a similar appearance in LM but the SEM pictures published in LANGe-Bertalot \& Krammer (1987) show an entirely different ultrastructure with raised external ribs, differently structured fibulae, the absence of fibulae extending across the entire valve and the presence of external proximal raphe endings.

\section{Nitzschia velazqueziana sp. nov. (Figs 183-201)}

\section{Description}

Light microscopy (Figs 183-197): Frustules with nitzschioid symmetry. Valves linear to narrowly lanceolate in valve view with weakly rostrate to cuneate apices. Valve dimensions $(\mathrm{n}=50)$ : length 19-34 $\mu \mathrm{m}$, width 2-3 $\mu \mathrm{m}$. Striae parallel throughout the entire valve, 24-26 in $10 \mu \mathrm{m}$. Marginal fibulae evenly spaced but of varying widths, $11-12$ in $10 \mu \mathrm{m}$. Canal raphe eccentric, raised slightly on a keel above the surface of the valve. Raphe slit continuous.

Scanning electron microscopy (Figs 198-201): Continuous raphe situated on a slight keel. Narrow hyaline area present opposite the raphe. External distal raphe ends hooked. Striae uniseriate, evenly spaced throughout the valve, mostly composed of elliptical areolae. 
Virgae much wider and thicker than the vimines. Striae from the valve face and the mantle ending in one, occasionally two rows of two smaller, round areolae, on both sides of the raphe. Internally, elliptical areolae occluded by hymenes. Internal distal raphe ends terminating in small, indistinct helictoglossae positioned on the valve mantle and prior to the hook of the external terminal fissure. Internally, canal raphe subtended by fibulae widening to the valve face to form round portulae. Fibulae evenly spaced throughout the valve every 1-2 striae.

Holotype: BR-4415 (Botanic Garden Meise, Belgium), fig. 187 represents the holotype.

Isotypes: PLP-286 (University of Antwerp, Belgium), BRM-ZU10/26 (HustedT Collection, Bremerhaven, Germany).

Type locality: Katia Lake II, Ulu Peninsula, James

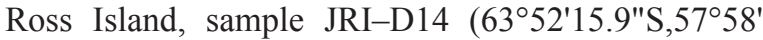
32.5"W) (Leg. L. NedBAlovÁ); coll. date 01/02/2008). Etymology: The species is named after DAVID VELAZQUEZ, member of the CCAMBIO-project.

Ecology and distribution: This new species has most likely been confused in the past with presumably cosmopolitan taxa such as Nitzschia perminuta of N. frustulum, making the exact distribution of $N$. velazqueziana not known at present. The species was the least common of the three taxa in the $N$. perminuta complex that were separated on Livingston Island and James Ross Island. The species was most commonly found in lakes and pools with a slightly alkaline $\mathrm{pH}(7.3-7.7)$ and a low to moderately high conductivity (50-600 $\left.\mu \mathrm{S} . \mathrm{cm}^{-1}\right)$. On Livingston Island, several large populations $(25-50 \%)$ were also found in wet mosses.

Taxonomical remarks: Several discriminating features separate Nitzschia velazqueziana from N. kleinteichiana and N. annewillemsiana. Nitzschia annewillemsiana has more convex valve margins, lacks the typical protracted, rostrate apices and has broader valves (3-4 vs. $2-3 \mu \mathrm{m})$. Nitzschia kleinteichiana shares the same valve outline with rostrate apices and almost parallel, only weakly convex margins (separating these species from $N$. annewillemsiana). The main difference can be seen in the structure of the raphe. Nitzschia kleinteichiana has clearly developed external proximal raphe endings whereas $N$. velazqueziana has a continuous raphe lacking proximal endings. A second important difference is the stria density: 27-30 in $N$. kleinteichiana vs. 24-26 in $10 \mu \mathrm{m}$ in N. velazqueziana. Additional differences can be found under Nitzschia kleinteichiana (see above). Nitzschia hantzschiana RABENH. has a similar valve outline with slightly broader valves $(3-5 \mu \mathrm{m})$ and a lower stria density (20-26 in 10 $\mu \mathrm{m})$ (KRAMMER \& LANGE-Bertalot 1988; Hofmann et al. 2011). Most typically, the latter species has a clearly developed central nodule resulting in a clear separation of the middle fibulae (Hofmann et al. 2011). Nitzschia alpina Hust. has less developed rostrate apices and wider valves $(3-4 \mu \mathrm{m})$ with more convex, less parallel margins (HofMANN et al. 2011).

\section{Nitzschia wilmotteana sp. nov. (Figs 202-218)}

\section{Description}

Light microscopy (Figs 202-216): Frustules with nitzschioid symmetry. Valves linear to narrowly lanceolate in valve view with narrowly-rounded to rostrate, produced apices. Valve dimensions $(n=30)$ : length 31.0-43.5 $\mu \mathrm{m}$, width 3.5-4.0 $\mu \mathrm{m}$. Striae not discernible in LM. Marginal fibulae evenly spaced but of varying widths, $12-14$ in $10 \mu \mathrm{m}$. Canal raphe eccentric, raised on a slight keel above the valve surface. Raphe slit continuous.

Scanning electron microscopy (Figs 217-218): Continuous raphe situated on a slight keel on the junction between valve face and mantle. Narrow hyaline area present opposite the raphe. External distal raphe endings are hooked. Striae composed of elliptical areolae, ca. 42 in $10 \mu \mathrm{m}$. Virgae slightly wider than vimines throughout the valve. Striae occluded by medially-placed cribra. Internal distal raphe endings terminating in helictoglossae prior to the hook of the external terminal fissure. From the interior, canal raphe subtended by small fibulae widening slightly to the valve face forming small round to elliptical portulae. Fibulae almost evenly spaced throughout the valve, one per every 2-3 striae.

Holotype: BR-4416 (Botanic Garden Meise, Belgium), fig. 206 represents the holotype.

Isotypes: PLP-287 (University of Antwerp, Belgium), BRM-ZU10/27 (HustedT Collection, Bremerhaven, Germany).

Type locality: Noodle Lake, Clearwater Mesa, James Ross Island, sample JRI-D63 (64 $02^{\prime} 02.1^{\prime \prime} \mathrm{S}, 57^{\circ} 41^{\prime}$ 00.4"W) (Leg. L. NedBalovÁ; coll. date 10/02/2009) Etymology: The species is named after our colleague Dr. Annick Wilmotte (Liège University, Belgium), principal investigator of the CCAMBIO-project.

Ecology and distribution: The largest population of the new taxon was found on the type locality in Noodle Lake. This stable, shallow lake is characterized by an alkaline $\mathrm{pH}(8.1)$, a rather high conductivity $(>1000$ $\mu \mathrm{S} . \mathrm{cm}^{-1}$ ) and elevated nutrient, phosphate and sulphate levels. Smaller populations were observed in other Clearwater Mesa lakes showing similar $\mathrm{pH}$ and conductivity values. A small population was found on Dart Island (South Shetland Islands) in a small half-frozen pool with an alkaline $\mathrm{pH}$ (9.4) and moderately high conductivity value $(574 \mu \mathrm{S} / \mathrm{cm})$, together with $N$. vandeputteana. The species has so far not been observed in other Maritime Antarctic lakes, although it is possible 
that some of the records of $N$. palea (KüTz.) GRUNOw species complex represent $N$. wilmottiana

Taxonomical remarks: Nitzschia wilmottiana resembles several Nitzschia taxa such as $N$. palea (and its variety debilis (KüTz.) GrunOw), N. intermedia HANTZSCH and $N$. pura Hust. Nitzschia palea is a very variable species but typically shows a very irregular spacing of the fibulae. TROBAJo \& Cox (2006) observed an irregular fibula pattern in the type material of $N$. palea although in their study on different $N$. palea clones a regular pattern was reported but not shown (TRовAJO et al. 2009). Nitzschia wilmottiana has always more or less regularly spaced fibulae. Moreover, N. palea usually shows more acutely rounded, shortly protracted, rostrate to sub- capitate apices whereas in N. wilmottia$n a$, they appear always rostrate and typically broadly rounded. Nitzschia palea, and especially the var. debilis has a lanceolate valve outline with rather convex margins, contrary to $N$. wilmottiana that has an almost linear outline with strictly straight margins (HoFMANN et al. 2011). Nitzschia intermedia HANTZSCH is usually larger with valve up to $200 \mu \mathrm{m}$ in length and a valve width of 4-7 $\mu \mathrm{m}$ (contrary to $N$. wilmottiana: valve width of 3.5-4 $\mu \mathrm{m})$. More important, the striae are discernible in $N$. intermedia $(20-33$ in $10 \mu \mathrm{m})$ whereas in $N$. wilmottiana the stria density is too high to make them easily visible in LM (ca. 42 in $10 \mu \mathrm{m}$ ). Finally, $N$. pura has similar valve dimensions but has more acutely ending apices, more convex margins giving the species a more lanceolate appearance and more irregularly spaced fibulae, separating this species clearly from $N$. wilmottiana (HoFMANN et al. 2011).

\section{Discussion}

Nitzschia is a large, morphologically diverse genus with over 900 taxa described worldwide (FoURTANIER \& KocIOLEK 2011), which have been placed within 6 to 20 subgroups or sections (SMITH 1853; MANN 1978; Cleve \& Grunow 1880, respectively). Some of these sections have been recognized subsequently as genera, such as Psammodictyon D.G.MANN in Round, R.M.CRAWFORD, \& D.G.MANN whereas several new genera were erected (e.g., Simonsenia LANGE-BERT.) or re-installed (e.g., Grunowia RABENH). Molecular investigations of Nitzschia taxa place the genus firmly within the Bacillariales (SIMS et al. 2006), but the genus itself as well as the largest section within the genus (i.e. Lanceolatae: 300 species; MAnN 1978) are not monophyletic (RIMET et al. 2011). Nitzschia has a worldwide distribution in marine and freshwaters, and has been reported from many kinds of habitats, including both clean and highly polluted ones (e.g., LowE 1974; Lange-Bertalot \& Metzeltin 1996). After an initial discovery phase of taxonomic work (e.g., CLEVE
\& GRUNOW 1880), some diatom taxonomists proposed a large-scale reduction in taxa (e.g. LANGE-BERTALOT 1977; Lange-Bertalot \& Simonsen 1978). While recognizing that the past taxonomic practice in general may have been too conservative in the naming of species, attention to this notoriously difficult genus has been modest. Even revisions to the flora by KRAMMER \& LANGE-Bertalot (1988) and Hoffman et al. (2011) have excluded any update to species treated as Nitzschia. Nevertheless, there are many species, marine, estuarine and freshwater, that are considered to be true endemics. Large numbers of endemic Nitzschia taxa have been described from Africa (e.g., MüLler 1905; Hustedt 1949), Indonesia (e.g., Hustedt 1942), and many other places, including the marine waters around Antarctica (e.g. Manguin 1957, 1960).

The species considered here from the Maritime Antarctic Region, except for $N$. australocommutata and $N$. vancauwenbergiana, would be assigned to the Lanceolatae Section of Nitzschia. Nitzschia australocommutata shares attributes with species such as $N$. commutata that have been assigned to the Dubiae/Bilobatae group within Nitzschia, by virtue of its highly eccentric raphe system and more or less lanceolate valve shape (Cleve \& Grunow 1880; Hustedt 1955). As both Lange-Bertalot \& Simonsen (1978) and KraMMER \& LANGE-BERTALOT (1988) indicate, there are many features that align the Dubiae/Bilobatae group with the Lanceolatae group of Nitzschia, but further research is necessary to better understand phylogenetic relationships of these groups to each other as well as within Nitzschia. Nitzschia vancauwenbergiana on the other hand belongs to the Lineares section, often considered a separate group (HustedT 1930).

For the other species discussed, based on their set of morphological features, they would all be assigned to the subgroup Lanceolatae. In detailing their valve morphology, however, we see variation in several features. Features detailed here that vary across the taxa considered include: presence/absence of keel, position of raphe, presence/absence of a central nodule, as well as position and structure of areolar occlusions.

For example, Nitzschia vandeputteana shows fibulae that are positioned on large, thickened interstriae running across the entire valve face, but this feature is unknown in the other taxa considered in our samples. Fibulae that extend partially across the valve face are seen in other species of Nitzschia species (i.e., partial fibulae; HAMSHER et al. 2014), such as N. homburgiensis, N. scalaris (EhrenB.) W.SMith, and N. palustris Hust., among others. In addition, $N$. denticula GRUNow, has almost entire fibulae. This latter species (and the presence of fibulae extending across the entire valve face) was thought to signify a species of Denticula and $N$. denticula was placed in Denticula as D. kuetzingii Grunow (Patrick \& Reimer 1975; Krammer \& Lange-Bertalot 1988; Lange-Bertalot \& Krammer 1993; see Hamsher et al. 2014). The condition in Nitz- 
schia vandeputteana differs from $N$. denticula since in $N$. vandeputteana there is a slightly inflated structure on the side of each fibula, and the height of the fibulae extending across the valve is the same. In $N$. denticu$l a$, the fibulae narrow from the raphe side towards the other side, and ribs may originate on the side opposite the fibulae and extend part-way towards the raphe side (HAMsHer et al. 2014).

Some species, such as N. paleacea and N. gracilis, have external hymenate occlusions in the areolae, while others have occlusions that are internallyplaced (e.g. N. kleinteichiana, N. vandeputteana), and others still (e.g., N. soratensis) have medially-placed occlusions. While authors have described differences in the arrangement of areolae (e.g., LANGE-BERTALOT $\&$ SimONSEN 1978), variation in the placement of the occlusions of the areolae of Nitzschia taxa has not had much discussion in the literature. This may have been due to the extensive use of transmission electron microscopy in detailing the pattern of and density of striae and areolae (e.g., LANGE-Bertalot 1977, 1980; Lange-Bertalot \& Simonsen 1978; Germain 1980), without being able to report the orientation of the valve exterior or interior relative to the path of electrons. In other groups of diatoms, location of the occlusions of areolae suggested to be phylogenetically informative, helping to recognize groupings at very high levels of taxonomic hierarchy (NIKOLAEV \& HARWOOD 2000), to genera (THERIoT et al. 1987).

Presence or absence of a central nodule in Nitzschia species was given great weight in the separation (and condensation) of Nitzschia species by LANGEBertalot \& Simonsen (1978). Lack of a central nodule is accompanied by a continuous raphe. Two distinct raphe branches are seen easily in taxa such as $N$. annewillemsiana, $N$. homburgiensis and $N$. soratensis, while a continuous raphe is seen in $N$. velazqueziana, $N$. vancauwenbergiana and $N$. stelmachpessiana. While in most species having two raphe branches, the external proximal ends are straight; in $N$. annewillemsiana the raphe ends are deflected towards the mantle.

Position of the raphe in this group of species from the South Shetland Islands and James Ross Islands are typical of the Lanceolatae subgroup of Nitzschia (KRAMmer \& LANGE-Bertalot 1988), with the raphe being strongly eccentric. In some cases this is evidenced by the raphe elevated in a small keel at the valve/mantle interface, such as is seen in N. velazqueziana, $N$. perminuta and $N$. annewillemsiana. In other species, the raphe is distinctly positioned on the valve mantle, and in cases like this there is no keel evident. Species with this arrangement include $N$. homburgensis, $N$. gracilis and, to a lesser degree, $N$. soratensis.

Areolae can be seen to be present (e.g., N. annewillemsiana, N. kleinteichiana) or absent ( N. velazqueziana) from the keel. Right next to the raphe-bearing margin, areolae can be double (N. kleinteichiana, $N$. velazqueziana, $N$. soratensis) versus single rows of areolae along the entire length of each stria (e.g., $N$. commutata, $N$. gracilis, $N$. vancauwenberghiana). Lange-Bertalot \& Simonsen (1987) identified a distinct group of species within Nitzschia taxa, such as $N$. romana GRUNOw and $N$. fonticola Grunow, that have double rows of areolae near the keel.

Variability in this range of valve features, from areolar occlusions, to striae organization to the raphe and keel suggest that these Nitzschia species are quite distinct for one another. While no unique approach to an overarching organization of Nitzschia has been published since that offered by CLEVE \& GRUNOw (1880), we feel these data will contribute (ultimately) to a better understanding of the genus. For these taxa specifically, it would seem that their variation speaks to them being derived from disparate sources, phylogenetically especially, but perhaps also biogeographically. Not only is there a gap, however, in the relationship between phylogeny and morphology, but also between morphology and biogeography. Further documentation of Nitzschia ultrastructure, especially with Field Emission SEM will help elucidate the types of similarities and differences across a wide range of morphological features, and hopefully contribute to our understanding of the relationship between morphology and phylogeny in this group.

\section{ACKNOWLEDGEMENTS}

This study was supported as a long-term research development project RVO no. 67985939. Samples on Byers Peninsula were taken in the framework of the IPY-Limnopolar Project POL2006-06635 (Ministerio de Ciencia y Tecnología, Spain). Sampling and/or observations on Dart Island, Deception Island, King George Island and Nelson Island were done within ДМУ 03-63 (Bulgarian Science Fund). Dr. B. Uzunov (University of Sofia), the staff of "Decepción" Base on Deception Island and "Bellingshausen" Station on King George Island are thanked for their help during the field work. Part of this research was funded within the FWO project G.0533.07 and by the BELSPO project CCAMBIO. Dr. AlEX BALL and the staff of the IAC laboratory at the Natural History Museum are thanked for their help with the scanning electron microscopy.

\section{REFERENCES}

Antoniades, D.; Hamilton, P.B.; Douglas, M.S.V. \& Smol, J.P. (2008): Diatoms of North America: The freshwater floras of Prince Patrick, Ellef Ringnes and northern Ellesmere Islands from the Canadian Arctic Archipelago. - Iconogr. Diatomol. 17: 1-649.

Aristarain, A.J.; Pinglot, J.F. \& Pourchet, M. (1987): Accumulation and temperature measurements on the James Ross Island ice caps, Antarctic Peninsula, Antarctica. - J. Glaciol. 33: 357-362.

Buörck, S.; Olson, S.; Ellis-Evans, C.; HÅkansson, H.; Humlum, O. \& Manuel de Lirio, J. (1996): Late Holocene palaeoclimatic records from lake sediments on James Ross Island, Antarctica. - Palaeogeogr., Palaeoclimat., Palaeoecol. 121:195-220.

Bourrelly, P. \& Manguin, E. (1954): Contribution à la flore algale d'eau douce des Iles Kerguelen. - Mém. Inst. Scientif. Madagascar, Sér. B, 5: 7-58.

Chipev, N. \& Veltchev, K. (1996): Livingston Island: an en- 
vironment for Antarctic life. - Bulg. Ant. Res.,.Life Sciences, 1: 1-6.

Chown, S.L. \& Convey, P. (2007): Spatial and temporal variability across life's hierarchies in the terrestrial Antarctic. -Phil. Trans. Roy. Soci., ser. B 362: 23072331.

Cleve, P.T. \& Grunow, A. (1880): Beiträge zur Kenntniss der Arctischen Diatomeen. - Kongl. Svenska-Vetensk. Akad. Handl.r 17: 1-121.

Denys, L. \& LANGe-Bertalot, H. (1998): Observations on two taxa of the section Nitzschiae Lanceolatae (Bacillariophyceae): Nitzschia blankaartensis sp. nov. and N. bulnheimiana. - Nova Hedwigia 67: 247-258.

Fourtanier, E. \& Kociolek, J.P. (2011): Catalogue of Diatom Names, California Academy of Sciences, On-line Version updated 19 Sept. 2011. - Available online at http://research.calacademy.org/research/diatoms/ names/index.asp

Germain, H. (1980): Trois nouvelles diatomées dans le bassin d'une serre à Angers (France). - Cryptog, Algol. $1: 19-27$.

Hamsher, S.A.; Graeff, C.L.; Stepanek, J.G. \& Kociolek, J.P. (2014): Frustular morphology and polyphyly in freshwater Denticula (Bacillariophyceae) species, and the description of Tetralunata gen. nov. (Epithemiaceae, Rhopalodiales). - P1. Ecol. Evol. 147: 346-365.

Hasle, G.R. (1994): Pseudo-nitzschia as a genus distinct from Nitzschia (Bacillariophyceae). - J. Phycol. 30: 1036-1039.

Hendey N.I. (1964): An introductory account of the smaller algae of British coastal waters. Part V. Bacillariophyceae (Diatoms). - 317 pp., Her Majesty's Stationery Office, London.

Hofmann, G.; Werum, M. \& Lange-Bertalot, H. (2011): Diatomeen im Süßwasser - Benthos von Mitteleuropa. Bestimmungsflora Kieselalgen für die ökologische Praxis. Über 700 der häufigsten Arten und ihre Ökologie. - 908 pp., A.R.G. Gantner Verlag K.G., Rugell.

Hustedt, F. (1930): Bacillariophyta (Diatomeae). In: A. PAScher (ed.), Die Süsswasser-Flora Mitteleuropas. Gustav Fischer, Jena. Zweite Auflage. Heft 10. 466 pp.

Hustedt, F. (1942): Süsswasserdiatomeen des indomalayischen Archipels und der Hawaii-Inseln. - Int. Rev. Ges. Hydrobiol. 42: 1-252.

Hustedt, F. (1949): Süsswasserdiatomeenaus dem AlbertNationalpark in Belgisch Kongo. - Exploration du Parc National Albert, Mission H. Damas (19351936), Institut des Parcs Nationaux du Congo Belge, Bruxelles 8: 1-199.

Hustedt, F. (1955): Marine littoral diatoms of Beaufort, North Carolina. - Duke University Marine Station, Bulletin, 6: 1-67.

Hustedt, F. (1959): Die Diatomeenflora des Salzlackengebietes im österreichischen Burgenland. - Österreichischen Akademie der Wissenschaften, Mathematische und Naturwissenschaftliche, K1. Abt. 1, 168: 387-452.

Kellogg, D.E.; Stuiver, M.; KellogG, T.B. \& Denton, G.H. (1980): Non-marine diatoms from Late Wisconsin perched deltas in Taylor Valley, Antarctica. - Palaeogeogr., Palaeoclimat., Palaeoecol. 30: 157-189.

Kellogg, T.B. \& Kellogg, D.E. (2002): Non-marine and littoral diatoms from Antarctic and Subantarctic regions. Distribution and updated taxonomy. - Diatom Monogr. 1: 1-795.

Kopalová, K. \& VAn de ViJver, B. (2013): Structure and ecology of freshwater diatom communities of Byers Peninsula (Livingston Island, South Shetland Islands). - Ant. Sci. 25: 239-253.

Kopalová, K.; Elster, J.; Nedbalová, L. \& Van de Vijver, B. (2009): Three new terrestrial diatom species from seepage areas on James Ross Island (Antarctic Peninsula Region). - Diatom Res.24: 113-122.

Kopalová, K.; Nedbalová, L.; de HaAn, M. \& Van de VIJVER, B. (2011): Description of five new species of the diatom genus Luticola (Bacillariophyta, Diadesmidaceae) found in lakes of James Ross Island (Maritime Antarctic Region). - Phytotaxa 27: 44-60.

Kopalová, K.; Veselá, J.; Elster, J.; Nedbalová, L.; KomÁrek, J. \& VAn de ViJver, B. (2012): Benthic diatoms (Bacillariophyta) from seepages and streams on James Ross Island (NW Weddell Sea, Antarctica). Plant Ecology and Evolution 145: 190-208.

Kopalová, K.; Nedbalová, L.; NÝvlt, D.; Elster, J. \& Van DE ViJver, B. (2013): Diversity, ecology and biogeography of the freshwater diatom communities from Ulu Peninsula (James Ross Island, NE Antarctic Peninsula). - Pol. Biol. 36: 933-948.

Kopalová, K.; Ochyra, R.; Nedbalová, L. \& Van de ViJVer, B. (2014): Moss-inhabiting diatoms from two contrasting Maritime Antarctic islands. - Pl. Ecol. Evol. 147: 67-84.

Košler, J.; Magna, T.; Mlčoch, B.; Mixa, P.; NÝvlt, D. \& Holub, F.V. (2009): Combined $\mathrm{Sr}, \mathrm{Nd}, \mathrm{Pb}$ and $\mathrm{Li}$ isotope geochemistry of alkaline lavas from northern James Ross Island (Antarctic Peninsula) and implications for back-arc magma formation. - Chem. Geol. 258: 207-218.

Krammer, K. \& Lange-Bertalot, H. (1988): Bacillariophyceae 2. Teil: Bacillariaceae, Epithemiaceae, Surirellaceae. - In: Ettr, H., Gerloff, J., Heynig, H. \& Mollenhauer, D. (eds): Süsswasserflora von Mitteleuropa, Band 2/2. - 596 pp., Gustav Fischer Verlag, Stuttgart-New York.

Lange-Bertalot, H. (1977): Eine Revision zur Taxonomie der Nitzschia lanceolatae Grunow. - Nova Hedwigia 28: 253-307.

Lange-Bertalot, H. (1978): Zur Systematik, Taxonomie und Ökologie des abwasserspezifisch wichten Formenkreis um "Nitzschia thermalis". - Nova Hedwigia 30: 635-652.

Lange-Bertalot, H. (1980): New species, combinations and synonyms in the genus Nitzschia. - Bacillaria 3: 41-77.

Lange-Bertalot, H. \& Bonik, K. (1976): Massenentwicklung bisher seltener und unbekannter Diatomeen als Indikator starker Abwasserbelastung in Flüssen. Algol. Studies 16: 303-332.

Lange-Bertalot, H. \& Krammer, K. (1987): Bacillariaceae Epithemiaceae Surirellaceae. Neae und wenig bekannte Taxa, neae Kombinationen und Synonyme sowie Bemerkungen und Erganzungen zu den Naviculaceae. - Bibl. Diatomol. 15: 1-289.

Lange-Bertalot, H. \& Krammer, K. (1993): Observations on Simonsenia and some small species of Denticula and Nitzschia. - Nova Hedwigia, Beih.106: 121-131.

Lange-Bertalot, H. \& Metzeltin, D. (1996): Indicators of 
Oligotrophy. 800 taxa representative of three ecologically distinct lake types. - Iconogr. Diatomol. 2: $1-390$.

Lange-Bertalot, H. \& Simonsen, R. (1978): A taxonomic revision of the Nitzschiae lanceolatae Grunow. 2. European and related extra-European fresh water and brackish water taxa. - Bacillaria 1: 11-111.

López-Martínez, J.; Serrano, E. \& Martínez de Pisón, E. (1996a): Geomorphological features of the drainage system. - In: LóPEZ-MARTínez, J.; Thomson, M.R.A. \& Thomson, J.W. (eds): Geomorphological map of Byers Peninsula, Livingston Island. BAS GEOMAP Series, Sheet 5-A. - pp. 15-19, British Antarctic Survey, Cambridge.

López-Martínez, J.; Hathway, B.; Lomas, S.; Martínez de Pisón, E. \& ARChe, A. (1996b) Structural geomorphology and geological setting. - In: LÓPEZ-MARtínez, J.; Thomson, M.R.A. \& Thomson, J.W. (eds): Geomorphological map of Byers Peninsula, Livingston Island. BAS GEOMAP Series, Sheet 5-A. - pp. 9-14, British Antarctic Survey, Cambridge.

Lowe, R.L. (1974): Environmental requirements and pollution tolerance of freshwater diatoms. US Environmental Protection Agency Publications, EPA 670/474-005. Cincinnati, Ohio. 334 pp.

Lundholm, N.; Hasle, G.R.; Fryxell, G.A. \& Hargraves, P.E. (2002): Morphology, phylogeny and taxonomy of species within the Pseudo-nitzschia americana complex (Bacillariophyceae) with descriptions of two new species, Pseudo-nitzschia brasiliana and Pseudo-nitzschia linea. - Phycologia 41: 480-497.

Manguin, E. (1957): Premier inventaire des diatomées de la Terre Adélie Antarctique. Espèces nouvelles. - Rev. Algol. nouvelle Série 3: 111-134.

Manguin, E. (1960): Les Diatomées de la Terre Adélie Campagne du Commandant Charcot 1949-1950. - Annls Sci. Nat.; Botanique, sér. 12: 223-363.

Mann, D.G. (1978): Studies in the family Nitzschiaceae (Bacillariophyta) [Ph.D. thesis]. - 386 pp, University of Bristol.

Morales, E.A. \& Vis, M.L. (2007): Epilithic diatoms (Bacillariophyceae) from cloud forest and alpine streams in Bolivia, South America. - Proc. Acad. Na. Sci Philadelphia 156: 123-155.

MüLLER, O. (1905): Bacillariaceen aus dem Nyassaland und einigen benachbarten Gebieten. III Folge, Naviculoideae-Naviculeae-Gomphoneminae-Gomphocymbellinae-Cymbellinae. Nitzschioideae-Nitzschieae. - (Engler's) Botanische Jahrbucher fur Systematik, Pflanzengeschichte, und Pflanzengeographie. Leipzig 36: 137-206.

Nedbalová, L.; NÝvlt, D.; KopáČeK J.; Šobr, M. \& Elster, J. (2013): Freshwater lakes of Ulu Peninsula (James Ross Island, NE Antarctic Peninsula): origin, geomorphology and physical and chemical limnology. - Ant. Sci. 25: 358-372.

Nelson, P.H.H. (1975): The James Ross Island Volcanic Group of north-east Graham Land. - Br. Ant. Surv. Sci. Rep. 54: 1-62.

Nikolaev, V.A. \& Harwood, D.M. (2000): Diversity and system of classification in centric diatoms. - In: WITKOWSKI, A. \& SiEMINSKA, J. (eds): The origin and early evolution of the diatoms: fossil, molecular and biogeographical approaches. - pp. 37-53, Polish Academy of Sciences, Krakow.
Ohtsuka, T.; Kudoh, S.; Imura, S. \& Ohtani, S. (2006): Diatoms composing benthic microbial mats in freshwater lakes of Skarvsness ice-free area, East-Antarctica. - Pol. Biosci. 20: 113-130.

Øvstedal, D.O. \& Lewis-Smith, R .I (2001): Lichens of Antarctica and South Georgia. A guide to their identification and ecology. - 411 pp., Cambridge University Press, Cambridge.

PAtrick, R. \& Reimer, C.W. (1975): The diatoms of the United States. Vol. 2. Entomneidaceae, Cymbellaceae, Gomphonemaceae, Epithemiaceae. - Monographs of the Academy of Natural Sciences of Philadelphia: $1-213$.

Peragallo, M. (1921): Diatomées d'eau douce. Première partie. Deuxième Expédition Antarctique Française (1908-1910) commandé par le Dr. J. Снавсот. Ouvrage publié sous les auspices du Ministère de l'Institution publique. Masson et cie : 1-38.

Rabenhorst, L. (1860): Die Algen Sachsens resp. Mittel-Europa's. Decas 95-96. no. 943-953.

Rimet, F.; Kermarrec, L.; Bouchez, A.; Hoffmann, L.; EcTOR, L. \& MEDLIN, L.K. (2011): Molecular phylogeny of the family Bacillariaceae based on 18S rDNA sequences: focus on freshwater Nitzschia of the section Lanceolatae. - Diatom Res. 26: 273-291.

Ross, R.; Cox, E.J.; Karayeva, N.I.; MANN, D.G.; PAdDock, T.B.B.; Simonsen, R. \& Sims, P.A. (1979): An amended terminology for the siliceous components of the diatom cell. - Nova Hedwigia, Beih. 64: 513-533.

Round, F.E.; Crawford, R.M. \& Mann, D.G. (1990): The diatoms. Biology and morphology of the genera. 747 pp., Cambridge University Press, Cambridge.

Sabbe, K.; Verleyen, E.; Hodgson, D.A.; Vanhoutte, K. \& Vyverman, W. (2003): Benthic diatom flora of freshwater and saline lakes in the Larsemann Hills and Rauer Islands, East-Antarctica. - Ant. Sci. 15: 227-248.

Sims, P.A.; ManN, D.G. \& Medlin, L.K. (2006): Evolution of the diatoms: insights from fossil, biological and molecular data. - Phycologia 45: 361-402.

Sмiтh, W. (1853): Synopsis of British Diatomaceae. -89 pp., John Van Voorst, London.

Theriot, E. \& Bradbury, J.P. (1987): Mesodictyon, a new fossil genus of centric diatom family Thalassiosiraceae from the Miocene Chalk Hills Formation, Western Snake River Plain, Idaho. - Micropaleontol. 33: 356-367.

Toro, M.; Camacho, A.; Rochera, C.; Rico, E.; Bañón, M.; Fernández-Valiente, E.; Marco, E.; Justel, A.; Avendaño, M.C.; Ariosa, Y.; Vincent, W.F. \& QueSADA, A. (2007): Limnological characteristics of the freshwater ecosystems of Byers Peninsula, Livingston Island, in maritime Antarctica. - Pol. Biol. 30: 635-649.

Trobajo, R. \& Cox E.J. (2006): Examination of the type material of Nitzschia frustulum, N. palea and N. palea var. debilis. In: Witкowski, A. (ed.) Proceedings of the $18^{\text {th }}$ International Diatom Symposium. Miedzyzdroje 2004, 431-445.

Trobajo, R.; Clavero, E.; Chepurnov, V.A.; Sabbe, K.; ManN, D.G.; Ishinara, S. \& Cox, E.J. (2009): Morphological, genetic and mating diversity within the widespread bioindicator Nitzschia palea (Bacillariophyceae). - Phycologia 48: 443-459.

Trobajo, R.; Rovira, L.; Ector, L.; Wetzel, C.E.; Kelly, M. 
\& ManN, D.G. (2013): Morphology and identity of some ecologically important small Nitzschia species. - Diatom Res. 28: 37-59.

Van de Vijver, B. \& Mataloni, G. (2008): New and interesting species in the genus Luticola D.G. Mann (Bacillariophyta) from Deception Island (South Shetland Islands). - Phycologia 47: 451-467.

Van de ViJver, B.; Frenot, Y. \& Beyens, L. (2002): Freshwater diatoms from Ile de la Possession (Crozet Archipelago, Subantarctica). - Bibl. Diatomol. 46: 1-412.

VAn de ViJver, B.; Gremmen ,N.J.M. \& Beyens, L. (2005): The genus Stauroneis (Bacillariophyceae) in the Antarctic region. - J. Biogeogr. 32: 1791-1798.

Van de Vijver, B.; Mataloni, G.; Stanish, L. \& Spaulding, S.A. (2010): New and interesting species of the genus Muelleria (Bacillariophyta) from the Antarctic Region and South Africa. - Phycologia 49: 22-41.

VAn de ViJver B.; Zidarova R. \& de HaAn, M. (2011): Four new Luticola taxa (Bacillariophyta) from the South Shetland Islands and James Ross Island (Maritime Antarctic Region). - Nova Hedwigia 92: 137-158.

Van de Vijver, B.; Tavernier, I.; KellogG, T.B.; Gibson, J.; Verleyen, E.; Vyverman, W. \& SabBe, K. (2012): Revision of type materials of antarctic diatom species (Bacillariophyta) described by West \& West (1911), with the description of two new species. Fottea 12: 149-169.

Van de Vijver, B.; Zidarova, R. \& Kopalová, K. (2014): New species in the genus Muelleria (Bacillariophyta) from the Maritime Antarctic Region. - Fottea 14:
$77-90$.

VAN DER WERFF, A. (1955): A new method of concentrating and cleaning diatoms and other organisms. - Verh. Int. Verein. Theor. Angew. Limnol. 12: 276-277.

Vinocur, A. \& Unrein, F. (2000): Typology of lentic water bodies at Potter Peninsula (King George Island, Antarctica) based on physical-chemical characteristics and phytoplankton communities. - Pol. Biol. 23: $858-870$

ZiDAROVA, R.P. (2008): Algae from Livingston Island (S Shetland Islands): a check-list. - Phytol. Balc. 14: 19-35.

Zidarova, R.; Van de Vijver, B.; Quesada, A. \& de HaAn, M. (2010): Revision of the genus Hantzschia (Bacillariophyceae) on Livingston Island (South Shetland Islands, Southern Atlantic Ocean). - Pl. Ecol. Evol.143: 318-333.

Zidarova, R.; Kopalová, K. \& Van de Vijver, B. (2012): The genus Pinnularia (Bacillariophyta) excluding the section Distantes on Livingston Island (South Shetland Islands) with the description of twelve new taxa. - Phytotaxa 44: 11-37.

Zidarova, R.; Kopalová, K. \& Van de ViJver, B. (2014): The genus Stauroneis (Bacillariophyta) from the South Shetland Islands and James Ross Island (Antarctica). - Fottea 14: 191-207.

(C) Czech Phycological Society (2016)

Received April 28, 2015

Accepted September 7, 2015 